\title{
STATE OF ALASKA
}

DEPARTMENT OF NATURAL RESOURCES

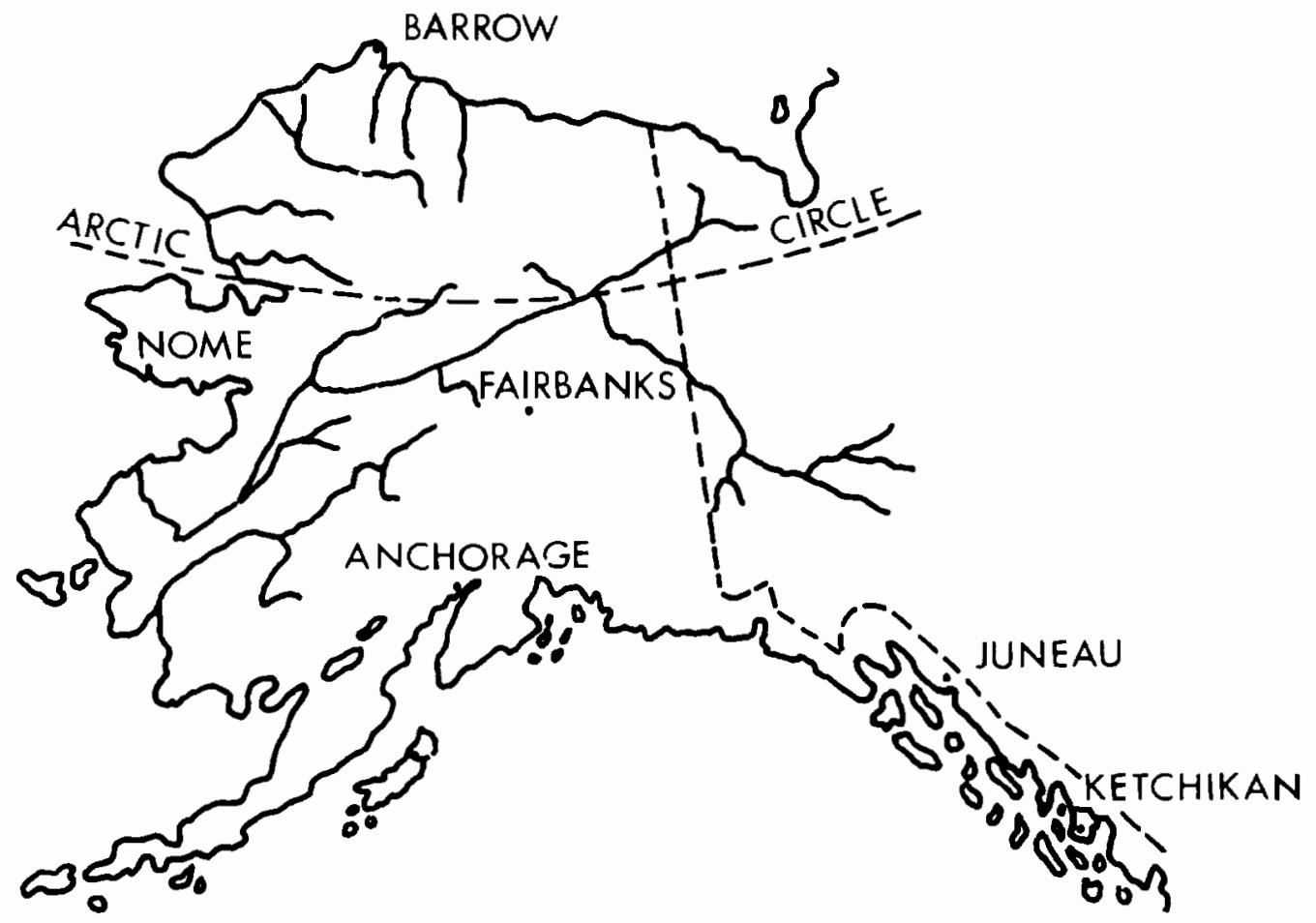

DIVISION OF MINES AND GEOLOGY

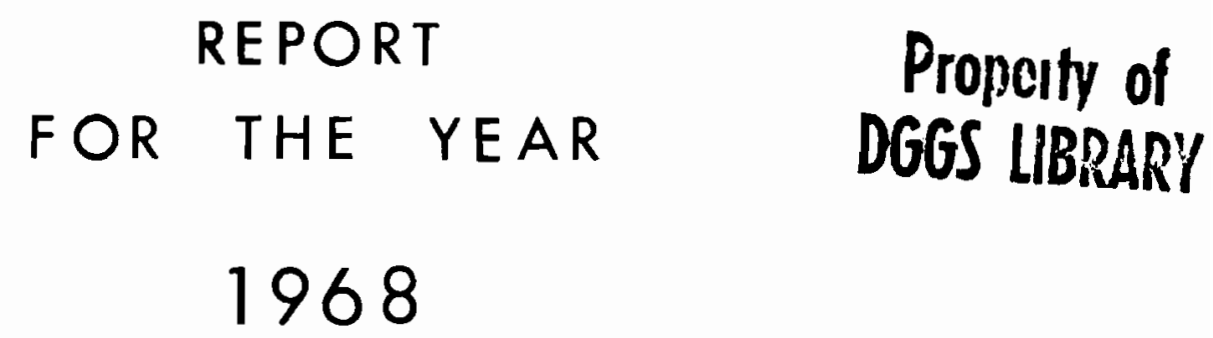

COLLEGE, ALASKA 


\section{STATE OF ALASKA \\ Keith H. Miller-Governor \\ DEPARTMENT OF NATURAL RESOURCES \\ Thomas E. Kelly-Commissioner \\ DIVISION OF MINES AND GEOLOGY \\ James A. Williams-Director}

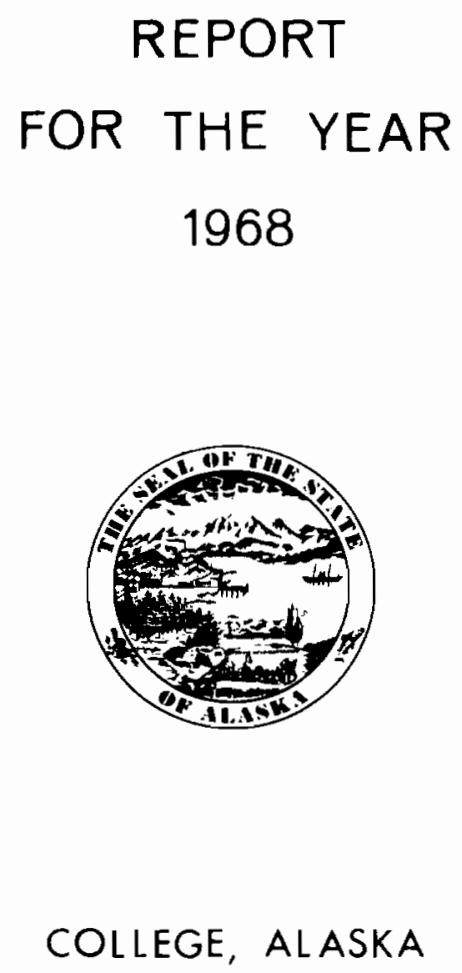




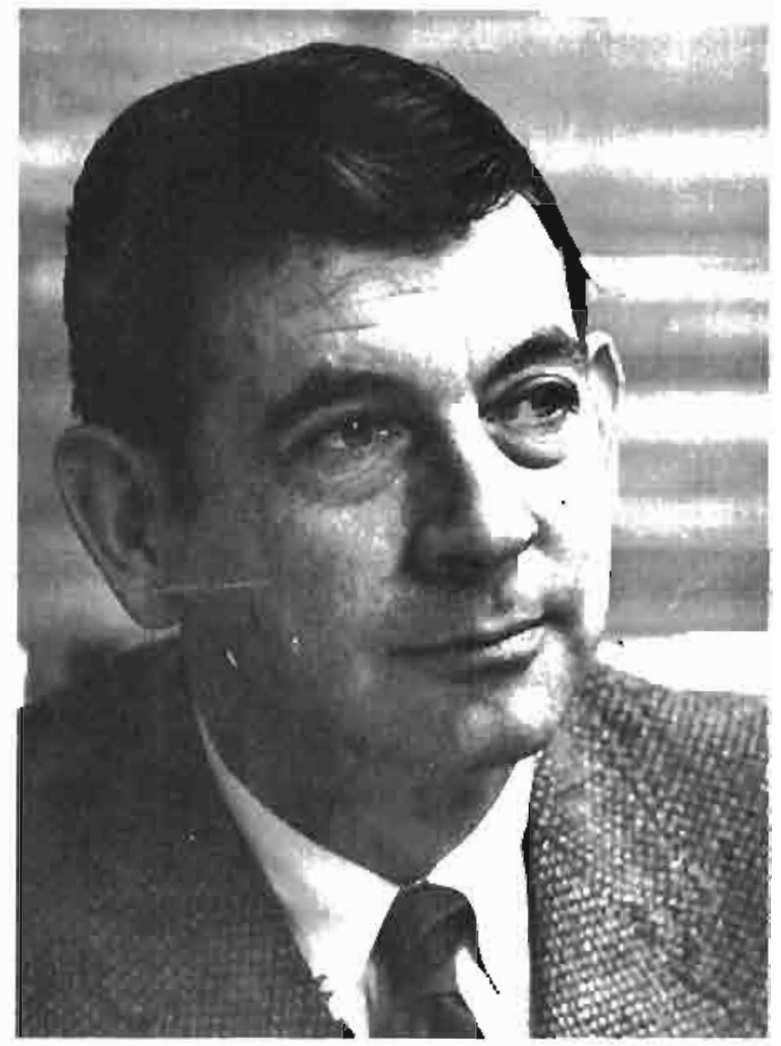

Keith H. Miller-Governor

STATE OF ALASKA 
DIVISION OF MINES AND GEOLOGY STAFF

DECEMBEF 31,1968

Headquarters Office, Maintenance Building, Box 5-300, College

James A. Williams, Director

Roderick R. Asher, Chief Mining Engineer

Theodore Vance, Mining Engineer

Robert E. Anderson, Mining Engineer

Crawford E. Fritts, Chief Mining Geologist

Gordon Herreid, Mining Geologist

Gilbert R. Eakins, Mining Geologist

Paul L. Andersorl, Laboratory Supervisor

Namok Cho, Assayer Chemist

Michael Mitche11, Jr., Geochemical Analyst

Donald R. Stein, Assayer

Charlotte M. Renaud, Draftsman

Eleanor L. Pierce, Administrative Assistant

Mary E. Shrewsbury, Mining Information Specialist

Mary L. Hartley, Secretary

Patricia H. nieterich, Clerk

Mildred Brown, Clerk Typist

Lynda R. Gudith, Clerk Typist

Anchorage Mining Information Office, 3001 Porcupine Drive

Marie Campbe11, Mining Information Specialist

Juneau Mining Information Office, Room 509 Goldstein Bldg., Pouch M

Mildred E. Zenger, Mining Information Specialist \& Administrative Assistant 
Honorable Thomas E. Kelly, Commissioner

Department of Natural Resources

Pouch $M$

Juneau, Alaska 99801

Dear Sir:

It is a pleasure to transmit to you this Annual Report of the Division of Mines and Geology covering the calendar year 1968. The report summarizes mining production, exploration, and developments during the year. The activities and accomplishments of the Division are outlined; our geological investigations and laboratory work are briefly described, and details on information and services available to the public are included.

Mining exploration work by major companies and private individuals is increasing, and interest in Alaskan mining possibilities continues to grow. However, we should by all possible means expand our geological work, institute new programs, provide incentives, disseminate useful and favorable information, and otherwise do all we can to encourage accelerated exploration and create an image of stable economic conditions. Followina discovery of an ore body, several years of exploration and development are usually required to bring it into production. This requires the industry to look many years ahead when making decisions on where to spend exploration money.

This Division will continue to foster and assist the growth of the mining industry in the best interests of the State.

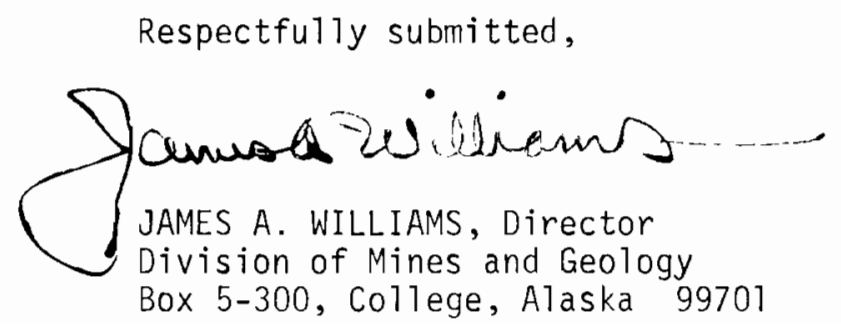


C ONTENTS

Page

DIVISION OF MINES AND GEOLOGY STAFF . . . . . . . . . . . . . . . . . . . . . III

LETTER OF TRANSMITTAL . . . . . . . . . . . . . . . . . . . . . . . . . . . IV

CONTENTS . . . . . . . . . . . . . . . . . . . . . . . . . . . . . . . . V V

FOREWORD ................................. 1

THE MINING INDUSTRY .................................. . . . . . . 3

Mineral Production . . . . . . . . . . . . . . . . . . . . . . . . . . . . 3

Prospecting and Exploration . . . . . . . . . . . . . . . . . . . . . 8

Prospecting Costs . . . . . . . . . . . . . . . . . . . . . . . . . 15

GOVERNMENT ACTIVITIES DURING 1968 . . . . . . . . . . . . . . . . . . . . . . . . . . . . 16

Areas Studied . . . . . . . . . . . . . . . . . . . . . . . . . 16

Reports Published by IJSGS and USBM During 1968............... . 18

ALSTRACTS OF FILLD AND LABORATORY REPORTS . . . . . . . . . . . . . . . . . . . . . . . . . . 21

Geological and Geochemical Study of Part of the Cosmos Hilis, Shungnak D-2

inuadrangle, Arctic Alaska. . . . . . . . . . . . . . . . . . . . . 21

Progress Report on Mapping in the Sinuk Area, Seward Peninsula, Aiaska. . . . . . 22

Geology and Geochemistry Near Sithylemekat Lake, Bettles quadrangle, Alaska . . 22

IJranium in Alaska . . . . . . . . . . . . . . . . . . . . . . . . . . . . . . . 23

Additional Geochem!ical Sampling of the Wood River-Tikchik Lakes Area, Southwestern Alaska . . . . . . . . . . . . . . . . . . . . 23

A Petrified Forest on Unga Island, Alaska Peninsula . . . . . . . . . . . . . 23

Geology and Geochemistry of Part of the Solomon Quadrangle, Seward Peninsula,
Alaska . . . . . . . . . . . . . . . . . . . . . . . . . . 24

A Geochemical Investigation at Cholmondeley Sound, Craig Quadrangle, Southeastern Alaska . . . . . . . . . . . . . . . . . . . . . . . . . . . . . . 24

Diana Lakes, Talkeetna Mountains, South-Central Alaska . . . . . . . . . . . . . 27

Preliminary Geologic and Geochemical Report on Little Falls Creek, Talkeetna Mountains Qquadrangle, South-Central Alaska... . . . . . . . . . . 27

Sitkinak Island Coal, Southwestern Alaska . . . . . . . . . . . . . . . . . . . 27

Bering River Coal Field, South-Central Alaska . . . . . . . . . . . . . . . . . 28

Analyses of Copper, Lead, and Zinc by Atomic Absorption Spectrography . . . . . 28

Rapid Radiometric Analysis for Equivalent IJraniun . . . . . . . . . . . . . . . 28

Laboratory Notes - Short Papers . . . . . . . . . . . . . . . . . . . . . . . . 29

SPECIAL REPORTS............................... 30

Results of Exploration Inquiry . . . . . . . . . . . . . . . . . . . . . 30

Mining Incentives . . . . . . . . . . . . . . . . . . . . . . 33

DIVISION OF MINES AND GEOLOGY . . . . . . . . . . . . . . . . . . . . . . . 38

General . . . . . . . . . . . . . . . . . . . . . . . . . 38

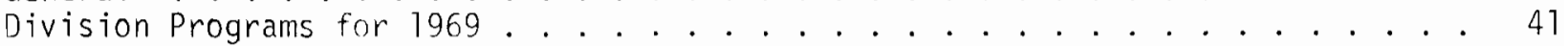

Division Reports... . . . . . . . . . . . . . . . . . . . . . . 43

Prospector Assistance Program . . . . . . . . . . . . . . . . . . . . . . . . . 44

COMPANIES CONSULTANTS MINERS PROSPECTORS . . . . . . . . . . . . . . . . . . . . . . 46

Companies . . . . . . . . . . . . . . . . . . . . . . . . . . . . . 46

Consultants . . . . . . . . . . . . . . . . . . . . . . . . . . . . . 48

Miners and Prospectors Active During 1968 . . . . . . . . . . . . . . . . . . . . . . 49

PRIVIOUS REPORTS ............................... 62 
Figure 1. Divisions of Alaska, As Used in This Report .. . . . . . . . . . . . . . . 2

2. Annual Mineral Production in Alaska 1900-1968 . . . . . . . . . . . . . . 7

3. Barometer of Exploration Activity in Alaska . . . . . . . . . . . . . . . . 14

4. Location Map Cholmondeley Sound, Alaska . . . . . . . . . . . . . . . . . . 26

\section{TABLES}

Table 1. Mineral Production in Alaska . . . . . . . . . . . . . . . . . . . . . . 3

2. Production of Maior Commodities Since 1949 Dollar Value (Thousands) . . . . 4

3. Physical Volume of Alaska Mineral Production . . . . . . . . . . . . . . . 4

4. Organization, Functions. and Costs - Division of Mines and Geology 1968 . . 39

5. Summary of Work Accomplished by Division of Mines and Geology in 1968... 40

6. Prospector Assistance Proaram - 1968 . . . . . . . . . . . . . . . . . . . 45 
FOR E WOR D

For convenience the State has been divided into six arbitrary units (fig 1). The boundaries of these units are based on bedrock geology, topography, parallels of latitude, and meridians of longitude. The five units are as follows:

1. Arctic Alaska, including the Brooks Range and other parts of the State north of the Arctic Circle.

2. Interior Alaska, including that part of the State south of the Arctic Circle, north of the Alaska Range, and east of meridian $153^{\circ} \mathrm{W}$.

3. Western Alaska, including the Seward Peninsula, Pribilof Islands, and other parts of the State south of the Arctic Circle, northwest of the Alaska Range, and west of meridian $153^{\circ} \mathrm{W}$.

4. Southwestern Alaska, including the Aleutian Islands, Kodiak Island, and the Alaska Peninsula south of parallel $59^{\circ} \mathrm{N}$.

5. South-Central Alaska, including the Alaska Range, adjacent mountainous terrain, and intermediate lowlands.

6. Southeastern Alaska, including all of the State east of meridian $147^{\circ} \mathrm{W}$. 


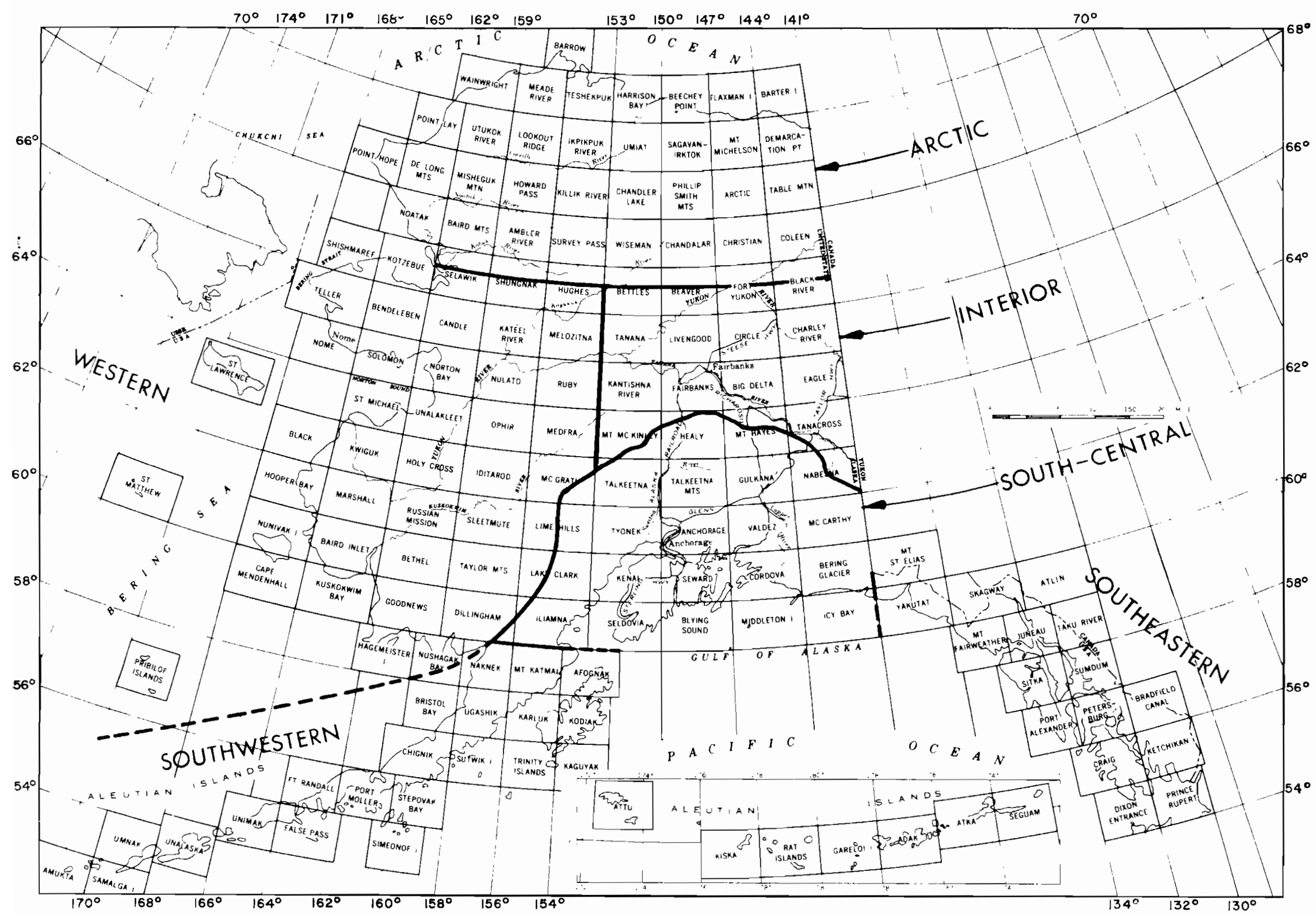

Figure I

DIVISIONS OF ALASKA, AS USED IN THIS REPORT 
THE M I N I NG INDUSTR

MINERAL PROOUCTION

Table 1 presents a comparison of mineral production in 1967 and 1968 . Total mineral production is estimated at $\$ 278.6$ mil1ion in 1968 versus $\$ 734.6$ million in 1967 . $0 i 1$ and gas production increased from $\$ 95.5$ million to $\$ 187.9$ million with the cook Inlet area being the predominant producer. Production of coal, stone, sand and gravel, silver, and gold all decreased in 1968. There was no copper production in 1968. The cumulative total mineral production of Alaska is now $\$ 1,967,328,000$ of which $\$ 759,853,000$ has been in gold.

After only ten years, the value of petroleun production in Alaska is rapidly approaching $2 / 3$ of the ninety year total of gold production values; it passed the half way mark in 1968.

Table 1

Mineral Production in Alaska

1967

$1968(1)$

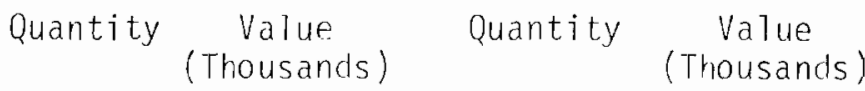

Antimony---short tons antimony content

Coal-........-thousand short tons

Gold-..............-.-. troy ounces

Natural Gas--.---nililion cubic feet

Petroleun, Crude-----thousand barrels

Sand and Gravel-..-thousand short tons

Silver--....-.-thousand troy ounces

Undistributed (4)

Totals

\begin{tabular}{rrrr}
10 & $W$ & & \\
930 & 7,178 & 812 & 5,034 \\
22,948 & 803 & 21,000 & 814 \\
$39,927(2)$ & 7,269 & $49,326(?)$ & 8,400 \\
$28,917(3)$ & 88,187 & $66,148(3)$ & 179,500 \\
22,370 & 26,248 & 17,585 & 20,729 \\
6 & 9 & 3 & 6 \\
& 4,924 & & 4,117 \\
\hline & $134,6 ? 8$ & & 218,600
\end{tabular}

(1) Figures for 1968, except petroleum and natural gas, are preliminary and subject to revision.

(2) Includes only gas sold.

(3) Includes only oil sold. Additional small amounts were produced during testing of new wells.

(4) Includes barite, gell stones, lead, mercury, peat, platinum group metals, stone, and tin.

W Withhe?d and included under "Undistributed" to avoid disclosing individual company confidential data.

Note: The above statistics were prepared under a cooperative agreement for the collection of mineral data between the Bureau of Mines, United States Department of the Interior, and the Division of Mines and Geology, Department of Natural Resources, State of Alaska. Figures for coal, petroleum, natural gas, and undistributed commodities are presented on authority of the Division of Mines and Geology only. 
Table 2

Production of Major Commodities since 1949

Dollar Value (Thousands)

\begin{tabular}{|c|c|c|c|c|c|c|}
\hline Year & Gold & Mercury & Coa 7 & $\begin{array}{c}0 i 7 \\
\text { and Gas }\end{array}$ & & $\begin{array}{l}\text { ductio } \\
17 \text { ions }\end{array}$ \\
\hline 1950 & $\$ 10,125$ & $\$$ & 3,033 & $\$$ & $\$$ & 17.9 \\
\hline 1957 & 8,387 & & 3,767 & & & 19.5 \\
\hline 1952 & 8,420 & 6 & 5,779 & & & 26.3 \\
\hline 1953 & 8,882 & 8 & 8,452 & & & 24.3 \\
\hline 7954 & 8,699 & 277 & 6,442 & & & 24.4 \\
\hline $195 b$ & 8,725 & 12 & 5,759 & & & 25.4 \\
\hline 1956 & 7,325 & 853 & 6,374 & & & 23.4 \\
\hline $195 /$ & 7,547 & 1,349 & 7,296 & & & 30.2 \\
\hline 1958 & 6,525 & 774 & 6,931 & & & 20.9 \\
\hline 1959 & 6,262 & 851 & 6,869 & 311 & & 20.5 \\
\hline 1960 & 5,887 & 940 & 6,318 & 1,496 & & 21.9 \\
\hline 1961 & 3,998 & 816 & 5,868 & 17,776 & & 34.7 \\
\hline 1962 & 5,784 & 711 & 6,409 & 31,657 & & 54.2 \\
\hline 1963 & 3,485 & 76 & 5,910 & 33,760 & & 67.8 \\
\hline 1964 & 2,045 & 95 & 5,008 & 35,490 & & 66. \\
\hline 1965 & 1,479 & 104 & 6,095 & 35,614 & & 83. \\
\hline 7966 & 956 & 101 & 6,953 & 50,418 & & 86.3 \\
\hline 1967 & 803 & 79 & 7,178 & 95,455 & & 134.6 \\
\hline 1968 & 814 & $78(1)$ & 5,034 & 187,900 & & 218.6 \\
\hline & $10 \overline{6,142}$ & 7,130 & 175,475 & $48 \overline{9,877}$ & &, 000 \\
\hline
\end{tabular}

(1) Estimate - no data available 1968.

Table 3

Physical Volume of Alaska Mineral Produc ion (1)

Mineral

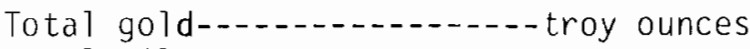

Total silver-...-.-.-.---troy ounces

Copper-....................... short tons

Coal-1........-short tons

Sand and gravel-..........-short tons

Crude petroleum-..-.-.-.-42 gal bbls

Natural gas-.-.........-million $\mathrm{ft}^{3}$

Stone-1...-...-short tons

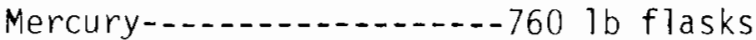

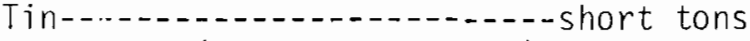

Chromite--(approx. $\left.45 \% \mathrm{CR}_{2} \mathrm{O}_{3}\right)$--long tons

Tungsten--.....-short ton units $\mathrm{WO}_{3}$

Antimony--(approx. 53\% Sb)---short tons

Lead-........-..-short tons

$$
\begin{gathered}
\text { Quantity } \\
29,944,000 \\
19,075,000 \\
690,011 \\
20,631,000 \\
171,530,000 \\
159,714,917(2) \\
266,935 \\
10,893,000(3) \\
34,999(4) \\
2,400(3) \\
29,000 \\
7,000 \\
3,443(4) \\
25,014
\end{gathered}
$$

Years

(1) Except platinum, uranium, barite, and other commodity figures which are confidential. 1968 production estimated and included in total.

(2) Dnly other crude petroleum recorded production was from the Katalla area. From 1901 to 1932, 154,000 barrels of 011 were produced there.

(3) Production data, if any, withheld in 1967 and 1968.

(4) Estimate - ro data available 1968.

$1880-1968$

$1906-1968$

$1880-1967$

$1951-1968$

$1958-1968$

1958-1968

1948-1968

$1921-1966$

1902-1968

$1902-1966$

1917-1957

1916-1958

1928-1968

1906-1968 


\section{Precious Metals}

Gold production continued to decline, but at a slower rate than in recent years. The value of gold produced showed an increase over 1967 as a result of higher gold prices on the free market. The United States Smelting Refining and Mining Company's last operating gold dredge worked on Hogatza River; it is expected to continue operating next year. The increasing price of gold has increased gold prospecting, and to some extent, mine development. A small increase in gold production is expected in 1969.

Platinum from the Goodnews Bay Mining Company remains the only major source of this precious metal in the United States. Exploration continued for platinum placer deposits in the Salmon River area. At least two major companies were searching for a lode source in the area.

Silver production declined by 50\% from 1967. During 1968 silver was produced only as a byproduct of gold operations. Several possible silver discoveries in south-central Alaska are encouraging for future silver production, though several years of exploration and development will be required before production begins.

\section{Base Metals}

Mercury production is reported to be less than $200 \mathrm{flasks.} \mathrm{Robert} \mathrm{Lyman} \mathrm{operated} \mathrm{his} \mathrm{mine} \mathrm{at}$ White Mountain, and development and production of the old Shaffer property on Cinnabar Creek was undertaken by Diamond Alkali Company. Holloway and Rehard continued exploration and development in the sleetmute area. Hope for increased production rests on the active exploration underway in the State.

Tin was mined by Richard Lee in a small placer operation at Tin City on the Seward Peninsula which accounted for the total production in the State.

Wrange11 Consolidated Mining Company shipped sillall amounts of copper from reworked dumps at the Kennecott property at McCarthy to Japan via Vancouver B. C. over the Alaska Highway in 1967 , but was idle in 1968.

\section{Coal}

Coal production suffered a setback with the May closure of the Evan Jones Mine in the Matanuska coal field, due to natural gas conversion at the military bases in the Anchorage area. Paul Omlin, operating the Premier Mine on a small scale, remains the only coal operator in the Matanuska field.

Coal production in the Nenana coal field on Healy Creek increased slightly from 1967 . The 10 percent increase resulted from the growing power demands in the Fairbanks area as well as increased military demands. Production comes from two companies operating open pit mines. Usibelli Coal Mining Company produced $61 \%$ of the coal from the Nenana field, mostly from Center Pit and Apex Pit. Vitro Minerals Corp. produced the balance of the coal from one mine, the West Pit. Golden Valley Electric Association began operating it's mine-mouth power plant during the summer. The power plant is located at Healy because it is cheaper to transport electricity than coal. According to G.V.E.A.'s Chief Engineer, utilizing coal at the mine location is expected to give them better cost per B.T.U. used than is enjoyed in Anchorage, where natural gas is the source of fuel.

Coal prices to the military bases in the Fairbanks area range from $\$ 6.00$ to $\$ 6.33$ per ton FOB Suntrana. Vitro contracted to mine and process 225,334 tons of coa 1 for $\$ 1,426,364$ FOB and Usibe11i contracted to mine and process 194,940 tons of coal for $\$ 1,169,640 \mathrm{FOB}$.

Cortella Coal Corp. of Cordova shipped four tons of coal samples from the Bering coal field to Japan for testing. 
Nonmetallics

Sand and gravel production decreased by 21 percent and stone production decreased by 31 percent of the 1967 figures as a result of decreased highway construction.

Barite, formerly shipped to Texas, is being processed in Alaska Barite Company's new plant at the mouth of the Kenai River. The barite is shipped from the company's mine at Castle Island near Petersburg to a new barge-mounted plant where drilling mud for the oil industry is produced.

Peat was produced in small quantities for use in local markets.

Jade production came from Jade Mountain and Cosmos Hills near Shungnak. Producers include Gene Joiner and Bill Munz. Alaska jade is purchased by jewelers and lapidary enthusiasts throughout North America and Europe. B and R Tug and Barge Company established a jade-cutting operation in Kotzebue. Native workers are employed. 


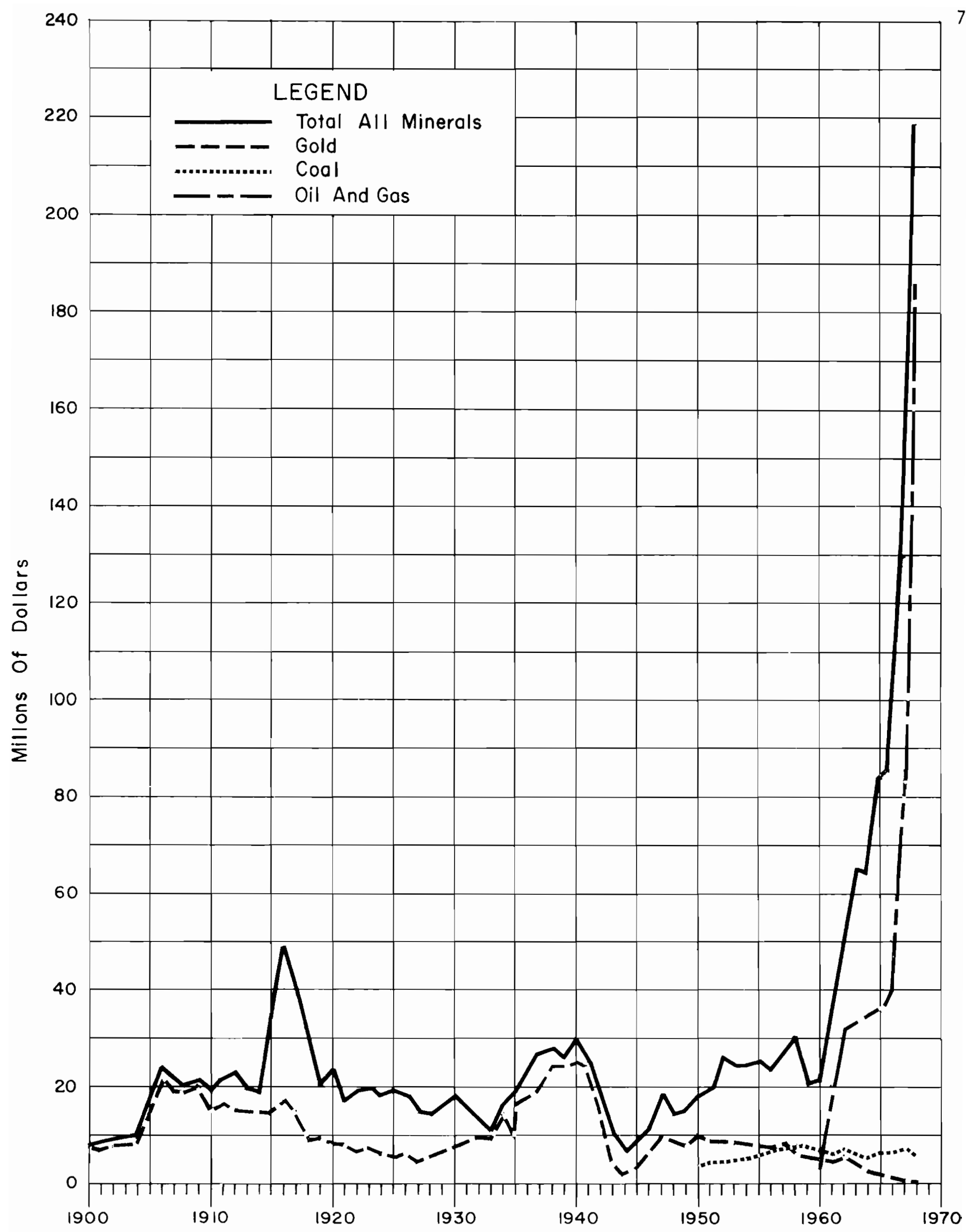

Figure 2

ANNUAL MINERAL PRODUCTION IN ALASKA, 1900-1968 


\section{PROSPECTING AND EXPLORATION}

\section{Arctic Alaska*}

Funds spent in Arctic Alaska for exploration probably totaled about $\$ 706,700$. Most of the 4,561 new claims staked in Interior, Western and Arctic Alaska (fig 3) are north of the Arctic Circle.

Development of the Chandalar gold mining and milling facilities began early in 1968 by investigating, purchasing, and shipping mine and mill equipment. Frank Birch, manager of Chandalar Gold Mining Co., reported that a seven-man crew moved into Chandalar in late March and cleared an airstrip on lake ice. During April and May, 730,000 pounds of equipment were flown to Chandalar and were moved by tractor and sled to the mine site at Tobin Creek. House trailers and steel buildings were erected. They will serve as living quarters, shop, assay lab, office, and other facilities at the mine site. Other work included road improvement and maintenance, further trenching, airstrip construction, millsite preparation, stripping, construction of a mill tailing ditch, pouring concrete floors for steel buildings, and clearing ice from underground workings. Plans for 1969 include completion of an airstrip that will accommodate C-82 and $\mathrm{C}-46$ aircraft. Millsites were leveled to grade this year and mill construction will continue next year. Ore from the Little Squaw and Mikado mines will be processed. In spite of a late spring and early fall, much progress was made during 1968.

Newmont Mining and U.S.S.R.\&M. explored under a joint venture agreement in the Noatak River area. This was their second season in that vicinity.

The Kennecott Copper Corp. has turned its Bornite copper property back to Bear Creek Mining Co. for further evaluation. It is understood that Bear Creek will continue drilling there. Bear Creek also drilled in at least one other site in the Kobuk country in 1968 . The company pursued intensive reconnaissance prospecting with a large crew in that area and elsewhere along the southern flaks of the Brooks Range.

Reed Mineral Exploration Co. of Pennsylvania extensively investigated a property long considered promising in the area of Wild River in the Bettles country.

The proposed railroad to the Arctic would help accelerate mining development as well as oil. This was pointed out by Natural Resources Commissioner Thomas E. Kelly in his address to the NORTH Commission. His report contained the following information:

"A long tectonic boundary between the Brooks Range geanticline and the Colville geosyncline is an excellent possibility for hardrock exploration. Several major faults have been mapped along it, more are probably hidden, and a number of granitic intrusives are known to exist along its general route.

"A radioactive anomaly exists in the Mt. Michelson granitic intrusive. Similar granitic intrusives exist along the north side of the Brooks Range which may be regarded as possible source rocks for uranium deposits which may exist in the north slope sediments.

"0il shale is contained in the Triassic rocks which mostly make up the southern section of the Arctic Foothi11s Province. This feature runs from the coast to the vicinity of Mt. Michelson. The U. S. Geological Survey reports that "oil shale is common in an almost continuous beit of Triassic rocks exposed along the north slope of the Brooks Range."

"Six phosphate locations are known, some in the region from the headwaters of the Colville River to Anaktuvuk Pass and some in the Mt. Michelson area. Additional phosphate deposits may exist in any of the limey metamorphosed sediments north of the Brooks Range.

* See Figure 1 for designation of geographical divisions. 
"Large areas of the North Slope are underlain by coal. Any of the Cretaceous rocks are likely to be coal-bearing. Coal reserves of northern Alaska total 19 billion tons of bituminous and 100 billion tons of lower grade coals. Some of the bituminous has been found by the USBM to have coking qualities when mixed with as 1 ittle as $15 \%$ Utah coal."

\section{Interjor Alaska}

Exploration expenditures in Interior Alaska during 1968 are estimated at $\$ 119,400$. The number of claims staked is not available; the data are combined with Western and Arctic Alaska (fig 3 ).

Busty Belle Mines, Inc., worked on developing its property in the Fox area. Limited underground drifting and cross-cutting was done. Surface prospecting consisted of trenching with a bulldozer. Work was started on a planned 50-ton-per-day mill.

Throughout the Interior, increased activity by individual prospectors was notable, probably caused by the promise of a rising gold price.

Pacific Construction Co. did extensive bulldozer trenching and rotary drilling on a large group of claims between Pedro and Fox Creeks.

Hanna Mining Corp. continued examining prospects and prospecting by geochemical methods.

Ed Hudson and Bill Ferguson continued exploration of their respective lode deposits near Livengood and on Ester Dome. Boyd Blair was again active at his property in the Bonnifield.

Placer prospectors active during the year included Ernest Wolff, Dan Coben, and Ed Farrell on separate creeks in the Manley Hot Springs district.

Companies showing interest in the region's possibilities by at least preliminary investigations included American Exploration, International Mineral and Chemical, Hecla, Phelps Dodge, American Metals Climax, and International Mine Service of Whitehorse.

\section{Western Alaska}

Offshore prospecting was again noteworthy in the Nome area. A 1967 study by the U. S. Geologican Survey, the U.S. Bureau of Mines and the University of Washington included offshore geophysical studies, bottom sampling and offshore drilling. Several valuable conclusions have been drawn as a result. In an abstract of this work, David M. Hopkins, U. S. Geologica] Survey Menlo Park, reported:

"Placer concentration of gold or tin may exist where beaches and streams have crossed these (glacial) drift areas during past intervals of low sea level."

Personnel of the U.S. Bureau of Mines research ship VIRGINIA CITY reported that gold was found in samples from each of the 49 holes drilled in 1967 in undersea placer deposits off the beaches of Nome.

Rowan Drilling Co. of Houston, Texas, was engaged by Ocean Science and Engineering to perform offshore exploration for gold in the Norton Sound area on permits totaling 85,000 acres. Offshore prospecting permits in the Nome region formerly controlled by Alaska Exploration Corp. of Anchorage were also being investigated by Rowan Drilling Co. The area is reported to aggregate some 100,000 acres.

She11 0i1 and American Smelting and Refining are drilling this winter on leases held by Shel1. The drilling is being done from sea ice. 
Amerada $0 i 1$ and 0ccidental $0 i 1$ hold offshore permits, and are planning future work. Global Marine is also involved in offshore work in the area.

Newnont and U.S.S.R.\&M. were associated in reconnaissance prospecting on the Seward Peninsula. Humble 0il (Mining Division) investigated prospects on Seward Peninsula.

Mercury prospecting in the lower Kuskokwim area increased. Alaska Mines and Minerals is reexamining the Red Devil Mine for more ore. Holloway and Rehard prospected and did some dri11ing on two or three well-known mercury prospects. Diamond Alkali expended considerable effort on the old Shaffer property on Cinnabar Creek. Out of the Kuskokwim district, near Dillingham, Clayton Rasmussen and partner did development work at the Red Top mercury property on Marsh Mountain.

Consultant James Wylie was active in the field on a number of prospects in various locations.

Rhinehart Berg was reported to be pursuing work with a crew, a drill, and a bulldozer at the old Independence property on the Kugruk River.

It is estimated that the total amount spent on exploration in Western Alaska is $\$ 1,243,000$. The number of new claims staked in Western Alaska alone is not known but the total is probably sma11, because much of the exploration involved offshore prospecting permits and leases.

\section{Southwestern Alaska}

This part of Alaska was relatively quiet, according to reports. There was continued interest in the Unalaska sulfur deposits near and in Makushin Volcano. The Division received many requests for information on this sulfur during the year. No direct reports of 1968 investigations were received, but at least one field party visited the area in late 1967.

Sinclair 0il Co. was reported active with a hard rock crew on the Alaska Peninsula doing reconnaissance exploration.

Truman Emberg prospected Alaskan Peninsula beach sands.

Expenditures for the region probably totaled in the neighborhood of $\$ 52,000$.

South-Central Alaska

This was the second most active part of Alaska in exploration, though the offshore work at the Nome area beaches may have caused greater expenditures of money in the Western division. Largely responsible for the increased activity in south-central Alaska were announcements by the U. S. Geological Survey of lead-zinc-silver mineralization of possible commercial interest found during the course of its heavy metals program the previous summer. These discoveries were in the Alaska Range southwest of Mt. McKinley National Park and west of the Talkeetna district. Exploration expenditures for this part of Alaska in 1968 are estimated at $\$ 848,700$. Figure 3 shows that 1,267 new mining claims were staked in south-central and southwestern Alaska during 1968. Most of this activity was in south-central Alaska.

A great deal of staking and prospecting activity was evident in the areas described above. As mentioned, this was largely brought on by U. S. Geological Survey Circulars 559 and 569. St. Eugene Mining Co., Alaskamin Co., and others were the most active. Possibilities for future developments in this new area are excellent. St. Eugene continued development of its property in the Kasna Creek area south of Lake Clark, as well.

Bear Creek Mining Co. pursued extensive reconnaissance work in the Alaska Range in addition to its work in Northern Alaska. 
Anchorage geologist Kirk Stanley kept a large crew of men busy drilling two properties in the Slana district with reported favorable results. One property is in a new area. Work by Stanley there resulted from earlier geological and geochemical work reported in a publication by a Division of Mines and Minerals geologist.

Alaskan Yukon Minerals, Inc. of Anchorage continued development of properties in the Copper River area.

Renewed interest was seen in the McCarthy district following earlier geophysical examinations and recent geochemical findings reported by the U. S. Geological Survey in their 1968 circular 604.

Alaska coal production suffered a setback with the closing of the Evan Jones Mine near Palmer. However, the future of Alaska coal looks encouraging. Substantial renewed interest is being shown in the Beluga Coal Field, west of Anchorage, by a number of major companies. Evidence of drilling or channel sampling was observed from the air in several places.

Cortella Coal Corporation of Cordova announced that several tons of coal samples were shipped to Japan for testing by five of Japan's leading coal importers. Cortella has leases in the Bering River Coal Field, which it drilled and trenched during the year. Further information on this is included elsewhere in this publication. In a news release, Victor $H$. Rhine, President of Cortella coa1, announced that the summer's exploration disclosed eight million tons of recoverable coal. The company hopes to begin production soon with an ultimate goal of one million tons per year. Geologists and engineers from the Sumitomo Shoji Corp. of Japan worked actively with Cortella in the exploration activities for part of the summer.

Duval Corp. of Vancouver and others participated in a drilling program at Orange Hill, in the Nabesna area. This is a copper-moly porphyry possibility that has intrigued mining geologists for many years. Longyear was the drilling contractor.

Leo Mark Anthony supervised a prospecting crew doing reconnaissance work in south-central Alaska and other parts of Alaska as usual. This party has been active under Tennessee Corp. and $i$ ts predecessors for more than ten years.

Wallace McGregor of Salt Lake City continued reconnaissance work with a crew of geologists in this and Interior regions.

¿7yde Wetherell of Anchorage formed the Alvenco Coilpany and was active in south-central as well as southeastern Alaska in reconnaissance work and claim staking.

"Rick" Richards continued prospect development work of a lead-zinc-silver prospect in the Slana district.

Gordon Burdick continued development of two copper properties in the McCarthy country. 01dtimer Martin Radovan reportedly had a Florida metallurgical firm interested in one or two of his prospects on Glacjer Creek in the same district.

Companies showing interest in various prospects in this part of Alaska included American Smelting and Refining, Bunker Hi11, Hanna, Phelps Dodge, American Metals Climax, American Exploration, and Guggenheim.

Southeastern Alaska

From all reports, southeastern Alaska was the busiest region by a wide margin in 1968 . One delighted prospector reported that there was a "mining company man behind every tree". Local helicopter services were used to capacity. Exploration expenditures for the region total an estimated $\$ 1,544,000$. The records section of the Division of Mines and Geology indicates that 1,540 new claims were staked in southeastern Alaska during 1968 ( $f$ ig 3). 
Newmont Exploration, Ltd. and Kendrick Bay Mining Co. entered into a joint venture agreement which provides for the future development and mining of the Kendrick Bay uranium holdings on Bokan Mountain on Price of Wales Island. Newmont and USSR\&M Co. together engaged in field investigations of a number of promising areas on Prince of Wales Island and elsewhere. Newmont with another partner drilled its patented nickel property beneath Brady Glacier in Glacier Bay National Monument. This deposit is reported to be similar to the famous Sudbury, Ontario nickel deposit.

An Anchorage syndicate known as Alvenco, under the direction of Clyde Wethere11, prospected and actively staked claims.

John Brockway diamond-drilled his copper prospect on Baker Peak on Chichagof Island.

Global Marine did some offshore prospecting with marine seismic work and bottom sampling in the Gastineau Channel and Stephens Passage near Juneau.

Humble $0 i 1$ was active in southeastern Alaska. Geophysical and geological reconnaissance were done over a large area.

Superior $0 i l$ Co. drilled the Muir Inlet "Nunatak" molybdenum prospect in Glacier Bay National Monument; Longyear Drilling $\mathrm{Co}$. was the contractor. This property has interesting "Climaxlike" geology.

In general, nickel prospecting in southeastern Alaska has become very active.

American Smelting \& Refining Co. investigated prospects, took an option on two and did some drilling.

Prospector Jim Walper of British Columbia put in his usual energetic season supervising a prospecting crew in southeastern Alaska and was instrumental in raising company interest in at least one additional prospect. Exploration continued at McLean Arm where Walper found a prospect earlier. It may be a copper porphry.

Utah Construction and Mining Company returned to its Mount Andrew copper-iron prospect on Prince of Wales Island for renewal of exploration work after an absence of several years.

A resumption of talks between $U$. S. Steel and Japanese interests regarding possible developInent of the Klukwan iron deposit was reported. This deposit has received no significant attention since 1959. New blast furnace techniques now enable the Japanese to cope with the titanium content. The deposit is estimated to contain some 800 million tons of ore, much of it in an alluvial fan.

International Nuclear Corp. did some preliminary investigations in preparation for field reconnaissance work in 1969.

Bill Huff and associates of Ketchikan had a very busy season developing prospects in several areas and negotiating with various companies for possible options.

Cambridge Mining Corp. started drilling on a copper show on Gravina Island late in the season.

American Metals Climax Corp. investigated some prospects. Phelps Dodge and Cyprus were both in the region with one or two men.

Prospectors Oscar Newlun, Paul Pieper, Don Ross, John Worthington, Alan McCay, John Ballard, James Mardis, Herman Kloss, and others were active on an individual basis. 
Genera 1

International Nuclear Corporation announced that it has entered the hardrock exploration field in Alaska. Phil R. Holdsworth has been named Alaska office manager for the company; his address is 1009 Mendenhall Apartments, Juneau, Alaska. Mr. Holdsworth, a mining engineer, was formerly the Commissioner of the Department of Natural Resources. He stated that International Nuclear is an "across the board" natural resources company. Early inquiries and preliminary studies by a number of other companies and syndicates not before active indicate increased exploration in 1969 over that of 1968.

Two officials of the J. S. Bureau of Indian Affairs talked with various mining authorities throughout Alaska on preliminary plans for opening certain Native reservations for mining. They were David Jones, Valuation Engineer, of Washington, and Charles H. Jones, Realty Officer, of Juneau. They explained that prospecting permits and leases on Indian reservations in the South 48 have been very successful and that Alaskan reservations should be made available for development without further delay. An announcement of details is expected early in the year so that exploration on the reservations can proceed during the 1969 field season.

Possibilities being considered for this new activity include one-year nonexclusive prospecting permits to be effective in 1969, followed by competitive bidding for exclusive prospecting permits with options to lease. The exclusive prospecting permits would be of longer duration--perhaps five years--and would probably be renewable at least once. Bidding would be on one of the following or a combination of straight bonuses, rentals, royalties, or work to be performed. Tracts would be large--up to 100,000 acres or more. Reservatjons being considered for opening include Akutan, Annette Island, Diomede Island, Karluk, Klukwan (parts not already under lease), Unalakleet, Venetie-Chandalar, and Wales.

The U. S. Bureau of Mines was active in various parts of Alaska on mining and seismic studies and research. Underground experimental work on frozen gravels was proceeding near Fairbanks at the close of the year.

The U. S. Geological Survey continues to be active throughout the State. Most of its field parties had both fixed wing aircraft and helicopter support, which gave easy access to areas otherwise unreachable and generally increased the efficiency of their field operations.

Total estimated exploration expenditure for 1968 is $\$ 4,513,800$. According to our records at the College office, 7,368 new mining claims were located during the year. 
INTERIOR, WESTERN AND ARCTIC

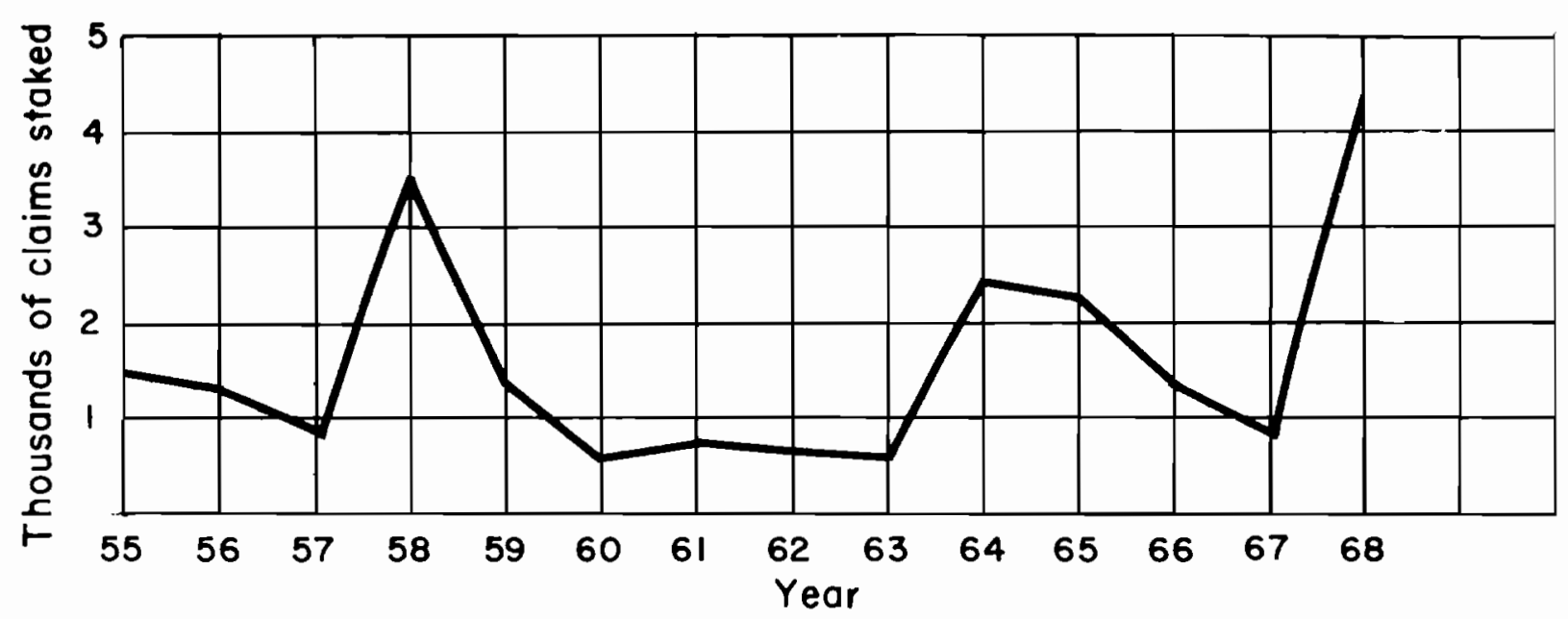

SOUTH-CENTRAL AND SOUTHWESTERN

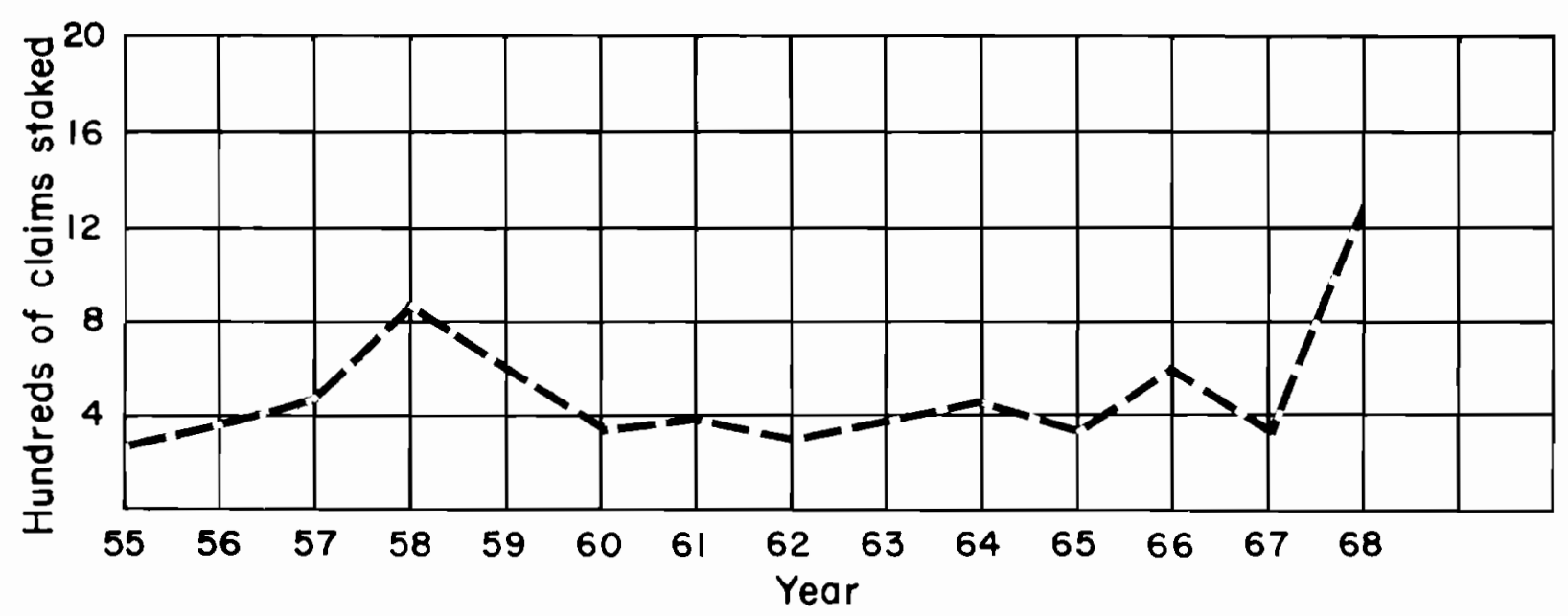

SOUTHEASTERN

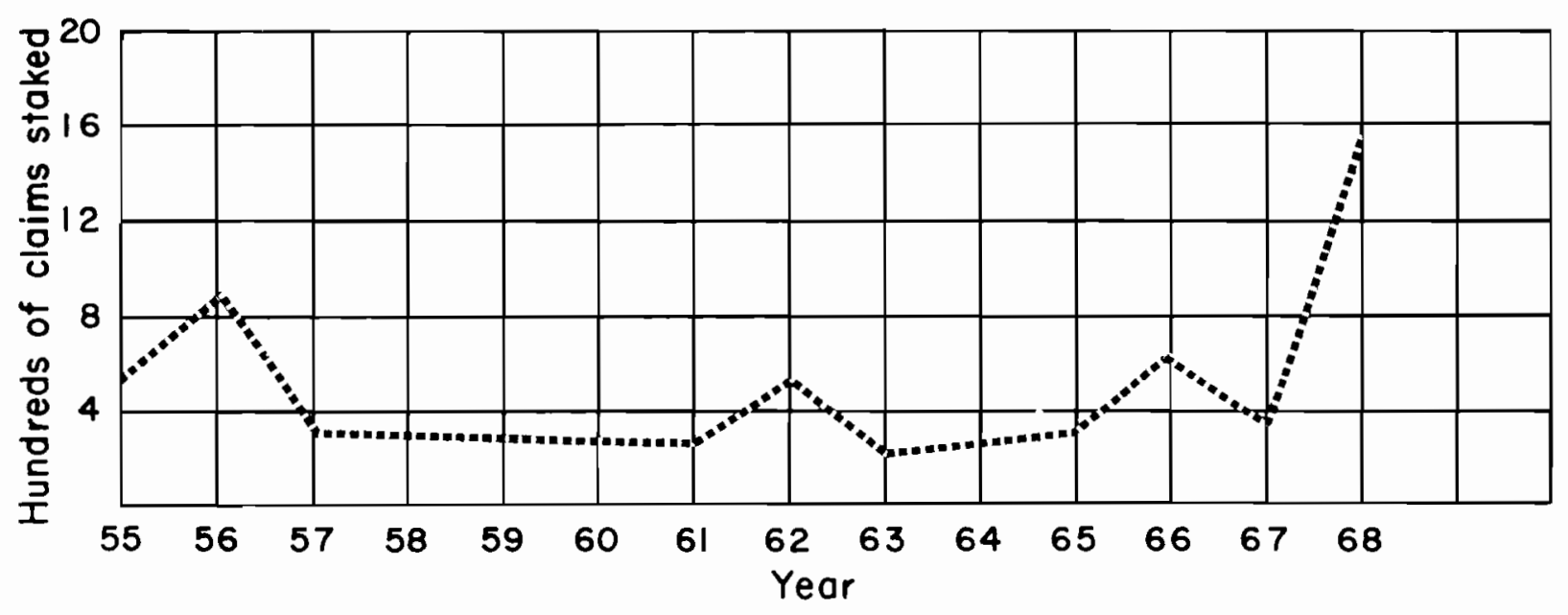

Figure 3

BAROMETER OF EXPLORATION ACTIVITY IN ALASKA BY NUMBER OF CLAIMS STAKED 


\section{PROSPECTING COSTS}

The costs presented below are based on a six-year average of expenditures by particpants in the State Prospector Assistance Program. The prospecting programs used in the calcuidtion represent a broad range of activities from reconnaissance prospecting by one man with minimal equipment to a crew of men utilizing heavy equipment for stripping overburjen. Consequently the cost for any individual prospecting venture may vary considerably from the average depending on the scale of the program.

The average expense is $\$ 22.06$ per man day. In the six-year period total expenditures were $\$ 117,580$ covering 5,059 man days. The total cost to the state during this period was $\$ 78,649.74$ or about 71 percent of the total.

Average costs for the program are given below:

\begin{tabular}{|c|c|c|}
\hline & \multicolumn{2}{|c|}{ Average cost Per Man viy } \\
\hline & $1963-1967$ & $1963-1968 *$ \\
\hline $\begin{array}{l}\text { Transportation } \\
\text { Food } \\
\text { Equipmerit and Supplies }\end{array}$ & $\begin{array}{r}8.61 \\
3.97 \\
10.01\end{array}$ & $\begin{array}{l}\$ 7.68 \\
3.87 \\
10.51 * \star\end{array}$ \\
\hline \multicolumn{3}{|c|}{$\begin{array}{l}\text { * Data for the year } 1968 \text { are incomplete; only those programs } \\
\text { reported by participants as of January 13, } 1969 \text { are included } \\
\text { in the average. }\end{array}$} \\
\hline
\end{tabular}

\footnotetext{
iransportation includes aircraft, tracked vehicles, rubber tired equipment, and boats used tj travel to and from prospecting areas and to transport supplies and equipment. Food includes groceries and other staple consumable items. Supplies include tools, camping equipment, prospecting equipment, fuel, and general supplies. Each year more heavy equipment is used to explore claims staked under the program than in previous years; thus there is a general increase in the cost of equipment and supplies.
}

Travel is mainly by charter aircraft. Sma 11 fixed-wing aircraft are available for charter in most Alaskan towns. Charter rates for a Piper Cruiser range from $\$ 20$ to $\$ 40$ per hour; charter rates for a Cessna 180 range from $\$ 40$ to $\$ 60$ per nour. Helicopters are available in Ketchikan, Juneau, Anchorage and Fairbanks; charter rates range from $\$ 100$ to $\$ 135$ per hour with a minimum guaranteed flying time of three hours per day. 
I pewik-Kukpuk

(USGS)

Peters-Schrader Lake

(USGS)

Tukuto Lake

(USGS)

Ipewik Lake

(USGS)

Kelley River (USGS)

Cosmos Hills-Shungnak

(DM\&G)

Yukon-Tanana Upland (USGS)

Eagle Quadrangle (USGS)

Fairbanks District (USGS)

Fish, Goldstream Creeks, Fairbanks District (USBM)

Fox

(USBM)

Livengood quadrangle (USGS)

Crazy Mountain-White Mountain (USGS)

Hogatza Project (USGS)

Seward Peninsula (USGS)

Seward Peninsula-Sinuk area, Solomon quadrangle (DM\&G)

St. Lawrence Island (USGS)

Nunivak Is land (USGS)

Bering Sea (USGS)

\section{AREAS STUDIED}

Arctic Alaska

oil shale study and geologic mapping

0il shale study and geologic mapping

$0 i 1$ shale study and geologic mapping

0 il shale study and geologic mapping

Geologic mapping

Geologic \& Geochemical study

\section{Interior Alaska}

Heavy metals project

Stream sediment and bedrock sampling

Heavy metals investigations and geologic mapping

Seismic studies to determine depth of overburden

A study underway to develop methods and systems for underground mining in frozen ground as part of the heavy metals program

Regional geologic mapping and study of mineral deposits

Correlation of volcanic rocks

Western Alaska

Heavy metals reconnaissance and regional mapping

Geologic mapping, search for lode sources of placer along several drainages, fossil studies

Geologic mapping and geochemical study

Heavy metal investigation and regional mapping

Study of volcanic explosion craters

Offshore sampling, seismic and magnetic reconnaissance

* State of Alaska, Division of Mines and Geology (DM\&G); U. S. Geological Survey (USGS); U. S. Bureau of Mines (USBM). 
Wood River-Tikchik Lakes (DM\&G)

Sitkinak Island

(DM\&G)

Unga Is land

(DM\&G)

Nixon Fork District (USGS)

Eastern Alaska Range (USGS)

Talkeetna-Central Alaska

Range (USGS)

Diana Lakes-Talkeetna Mountain B5-B6 quadrang 7 e (DM\&G)

Little Falls Creek-Talkeetna Mountains, B3-B4-C3-C4 quad. (DM\&G)

Central Alaska Range (USGS)

Nuka Bay (USGS)

Bering River Coal Field (DM\&G)

Yakutat area

(USGS)

Juneau Project (USGS)

Chormonde ley Sound ( $D M \& G$ )

Sumner Strait Project (USGS)

Hyder Area (USGS)

Annette Is land (USGS)

Alaska-general (DM\&G)
Southwestern Alaska

Geochemical investigation

Coal outcrop investigation

Petrified forest investigation

South-Central Alaska

Test geophysical and geochemical techniques in locating buried mineralized zones.

Geological mapping and geochemical studies in the Nabesna River drainages.

Geological and geochemical studies in the northern

Talkeetnas, Valdez Creek and Reindeer Hills

Geological and geochemical study

Geological and geochemical study

Placer studies in the Yentna, Nelchina, Valdez, Eureka, Chistochina, Ahtell and Chisana mining districts

offshore study of bottom sediments

Coaj investigation in Carbon Creek area

Southeastern Alaska

Geologic mapping and heavy metals investigation

Regional structure, metamorphic stratigraphy and detailed geologic mapping of the Juneau gold district

Geochemical investigation

Geologic mapping in the southern part of area, Silurian and Devonian limestones studied in a number of locations Heavy metals study started

Geologic mapping completed

Genera 1

Uranium study and investigations 
REPORT: PUBLISHED BY USGS AND USBM DURING 1968

The USGS and USBM publications 1 isted below were released in 1960. Open file reports are usually available for study at the various USGS, USBM and Division of Mines and Geology offices in Alaska. Copies of open file reports can usually be obtained at private expense. USGS numbered bulletins and professional papers may be purchased from the U. S. Governinent. printing office or over the counter at the USGS Public Inquiry Office in Anchorage. USGS circulars are free. USBM information circulars and reports of investigations may be purchased from the Publication Distribution Office, U. S. Bureau of Mines, Pittsburgh, Pa. Division publications are listed elsewhere in this report.

\section{USBM Open File Reports}

Soil sampling at the Egnaty Creek mercury prospect, Kuskokwim River Basin, Alaska, by R. P. Maloney

\section{USGS Open File Reports}

Metallic mineral resources map of the Chandalar quadrangle Aiaska, compiled by Edward $\mathrm{H}$. Cobt Metallic mineral resources map of the Wiseman quadrangle Alaska, compiled by Edward H. CoDb Metallic mineral resources map of the Healy quadrangle Alaska, compiled by Edward H. Cobb Metallic mineral resources map of the Mount Hayes quadrangle Alaska, compiled by Edward H. Cobb Metallic mineral resources map of the Bendeleben quadrangle Alaska, compiled by Edward H. Cobb Metallic mineral resources map of the Candle quadrangle Alaska, compiled by Edward H. Cobb Metallic mineral resources map of the Solomon quadrangle Alaska, compiled by Edward $H$. Cobb Metallic mineral resources map of the Seward and Blying Sound quadrangles Alaska, compiled by Edward H. Cobb

Platinum deposits of Alaska, by John B. Mertie, Jr.

Geology of the Iliamna quadrangle, Alaska, by Robert L. Detterman and Bruce L. Reed Metallic mineral resources map of the Nome quadrangle Alaska, compiled by Edward H. Cobb Metallic mineral resources map of the Teller quadrangle Alaska, compiled by Edward H. Cobb and C. L. Sainsbury

Bering Sea shelf seismic reflection records, 1967 (R/V Thompson) by David W. Scholl and David M. Hopkins

Geology of the Golden Zone mine area, Alaska, by C. C. Hawley, Allen L. Clark and J. Alan Benfer

Alaskan gravity base station network, by David F. Barnes

Metallic mineral resources map of the Skagway quadrangle Alaska, compiled by Edward $H$. Cobt Metalir mineral resources rilap 3 the Mount fairweather quadrangle ATaska, compiled by cuward :4 cobb

Metalitic mineral resources man is the untau quadrangle Alaska, compiled by tawand h. Cob 
Metallic mineral resources map of the Sitka quadrangle Alaska, compiled by Edward H. Cobb Metallic mineral resources map of the Sumdum quadrangle Alaska, compiled by Edward H. Cobb Metallic mineral resources map of the Port Alexander quadrangle Alaska, compiled by Edward H. Cobb

Metallic mineral resources map of the Petersburg quadrangle Alaska, compiled by Edward H. Cobb Metallic mineral resources map of the Craig quadrangle Alaska, compiled by Edward H. Cobb Metalijc mineral resources map of the Ketchikan quadrangle Alaska, compiled by Edward H. Cobb Metallic mineral resources map of the Dixon entrance quadrangle Alaska, compiled by Edward $H$. Cobb

Geological interpretation of reconnaissance aeromagnetic survey of northeastern Alaska, by W. P. Brosge, Earl E. Brabb and Elizabeth R. King

Geochemical investigations of Antimony Creek antimony prospect northern Talkeetna Mountains, Alaska, by C. C. Hawley, A. L. Meier and R. L. Miller

Metallic mineral resources maps of nine Alaska quadrangles (Holy Cross, Kotzebue, Melozitna, Norton Bay, Nulato, Prince Rupert, Survey Pass, Taku River, Unalakleet) compiled by Edward H. Cobb

Miscellaneous geologic Investigation Map I-530, Regional geologic map of the Selawik and southeastern Baird Mountairls quadrangles, Alaska by W. W. Patton Jr. and T. P. Miller

Reconnaissance geologic map of the Tanacross quadrangle Alaska, by Helen L. Foster

Preliminary geologic map of the Eagle B-1 and C-l quadrangles Alaska, by Helen L. Foster and Terry C. Keith

Geology and lode gold deposits of the Nuka Bay area, Kenai Peninsula, by Donald H. Richter

Results of stream-sediment sampling between Windy Fork and Post River, southern Alaska Range, by Raymond L. El]iott and Bruce L. Reed

Results of stream-sediment sampling in parts of the southern Alaska Range, by Bruce L. Reed and Raymond L. E11iott

Reconnaissance geology, mineral occurrences and geochemical anomalies of the Yentna district, Alaska, by A. L. Clark and C. C. Hawley

Metallic mineral resources map of the Baird Mountains quadrangle Alaska, compiled by Edward H. Cobb

Metallic mineral resources map of the Ambler River quadrangle Alaska, compiled by Edward H. Cobb

Metal1ic mineral resources map of the Shungnak quadrangle Alaska, compiled by Edward H. Cobb Metallic mineral resources map of the Hughes quadrangle Alaska, compiled by Edward H. Cobb Metallic mineral resources map of the Ruby quadrangle Alaska, compiled by Edward H. Cobb Metallic mineral resources map of the Ophir quadrangle Alaska, compiled by Edward H. Cobb 
Metallic mineral resources map of the Iditarod quadrangle Alaska, compiled by Edward H. Cobb Metallic mineral resources map of the Medfra quadrangle Alaska, compiled by Edward $\mathrm{H}$. Cobb Metallic mineral resources map of the McGrath quadrangle Alaska, compiled by Edward H. Cobb Geochemical reconnaissance maps of granitic rocks, Coleen and Table Mountain quadrangles Alaska, by W. R. Brosge and H. N. Reiser

Gold gradients and anomalies in the Pedro-Cleary Summit area, Fairbanks district, Alaska, by R. B. Forbes, H. D. Pilkington and Daniel B. Hawkins

Description of the Ruth Creek, Lillian Creek, Griffin, 01d Smoky, Sunshine No. 2, and 01ive Creek lode prospects, Livengood district, Alaska, by R. L. Foster

\section{USGS Circulars}

No. 559, Lead, zinc, and silver deposits of Bowser Creek, McGrath A-2 quadrangle, Alaska, by B. L. Reed and R. L. Elliott

No. 564, Occurrences of gold and otıer metals in the upper Chulitna district Alaska, by C. C. Hawley and Allen L. Clark

No. 565, Cassiterite in gold placers at Humboldt Creek Serpentine-Kougarok area, Seward Peninsula, Alaska, by C. L. Sainsbury, Reuben Kachadoorian, Thomas F. Smith and William C. Todd

No. 593, Distribution of gold and some base metals in the Slana area, Eastern Alaska Range, Alaska, by Donald E. Richter and Neal A. Matson, Jr.

No. 592, Interpreting pan-concentrate analyses of stream sediments in geochemical exploration for gold, by R. P. Fischer and F. S. Fisher

No. 570, Suggested areas for prospecting in the Central Koyukuk River region, Alaska, by Thomas P. Miller and Oscar J. Ferrians, Jr.

No. 590, Potential for lode deposits in the Livengood gold placer district, east-central Alaska, by R. L. Foster

\section{USGS Bulletins}

No. 1246, Metalliferous Tode deposits of Alaska, by Henry C. Berg and Edward H. Cobb

No. 1249, Geology of the Johnson River area, Alaska, by G. William Helmes and Helen L. Foster

No. 1236, Geology of the Lake Peters area Northeastern Brooks Range, Alaska, by Bruce L. Reed

USGS News Releases

Conner-silver-zinc denosits east of Farewell and north of Shellabarqer Pass. 
A BSTRACTS OF FIELD AND LABORATORY REPORTS

\section{GEOLOGICAL AND GEOCHEMICAL STUDY OF PART OF THE COSMOS HILLS, SHUNGNAK D-2 OUADRANGLE, ARCTIC ALASKA}

Crawford E. Fitts, Chief Mining Geologist Division of Mines and Geology

Detailed geologic mapping of bedrock and geochenical sampling of stream sediments were undertaken in a 50-square-mile area about 5 miles southeast of Bornite, Alaska, approximately 300 miles northwest of Fairbanks. The field work was part of a proposed 2- or 3-year study of the entire Cosmos Hills window. This geologic structure includes the encouraging show of copper mineralization at Bornite now being explored by the Bear Creek Mining Company.

The Cosmos Hills window is about 20 miles long and 8 miles wide. It extends east southeastward across the boundary between the Ambler River and Shungnak quadrangles. Mapping was begun in the Shungnak D-2 quadrangle of the 30-minute series, because this area offered 1) the best topographic base map, 2) the widest variety of 1 ithologies, 3) the most complex geologic structure, and 4) the best opportunity to study the relationship between the emplacement of granite and the deformation, metamorphism and possible mineralization of adjacent strata.

Bedrock in the mapped area consists mainly of a thick sequence of pelitic rocks (slate, phyllite and schist), dolomitic limestone, extrusive and intrusive greenstone, intrusive serpentinite, and conglomerate, sandstone and mudstone. These rocks range in age from Devonian to Cretaceous. Pelitic rocks near the Kogoluktuk River have been intruded and metamorphosed by medium-grained gneissic granite of probable early cretaceous age, which forms a nearby circular pluton about 1 mile in diameter. The metamorphosed strata are characterized by porphyroblasts of garnet and albite, which decrease in abundance away from the granite.

Structural features include 1) a dome surrounding the granite pluton, 2) a horst 6 miles wide containing the dome and pluton, and bounded by northeast-trending, high-angle faults of large throw. 3) at least one northwest-trending fault within the window, 4) at least two south-dipping thrust faults of unknown displacement, which post-date the horst and form the southern edge of the window, and 5) several high-angle faults of moderate to large displacement, which postdate the thrusts. The thrust faults are indicated clearly by marked discordances in the attitude of bedding on opposite sides of these fractures, especially in the vicinity of Ferguson Peak, Inerevuk Mountain, and an unnamed peak 2 miles northeast of the Dahl Creek airfield.

A new fossil locality was found on the north side of Ferguson Peak. Numerous moderately well preserved parts of crinoid stems were found in blocks of light-gray limestone derived from similar limestone exposed near the mountain summit. This rock appears to be interlayered with greenschists bounded by the two main thrust faults. The crinoid stems are the only fossils found so far in the map area. Crinoids have not been reported from other parts of the cosmos Hills.

Geochemical work involved 124 samples collected from 10 main streams and their tributaries. The samples were analyzed by the U.S. Geological Survey in Denver. A table of analyses was prepared in Fairbanks. No conspicuous anomalies were found. Thus no direct relationship between granite emplacement and copper mineralization can be shown at present. However, the data at hand indicate a definite relationship between the chemical composition of sediments in some of the stream valleys in the map area and the chemical composition of the predoninant bedrock exposed in the respective drainage basins.

Small-scale placer mining for gold has been done along Dahl, California and Lynx Creeks. Dlacer workings apparentiy were most productive in the upper parts of the Dahl creek and California creek valleys, which are underlain by phyllite cut by numerous quartz veins. The veins presumably yielded gold, which the strealns carried into the placer deposits. Today, placer claims along Dahl creek are being reworked for the popular "Alaskan jade", which is obtained from boulders derived from numerous sma 17 bodies of serpentinite exposed in tributary valleys inside the window. 
PROGRESS REPORT ON MAPPING IN THE SINUK AREA, SEWARD PENINSULA, ALASKA

Gordon Herreid, Mining Geologist

Division of Mines and Geology

Investigations were continued in the sinuk area, 25 miles northwest of Nome. A number of critical areas were mapped in detail, and mapping was extended west of the Sinuk River to include the American Lode. Previous work in the area by the author was reported in Division of Mines and Minerals Reports 24 and 29.

The marble masses that cap the hills in parts of the area appear to have been thrust over the schist. The marble is cut by many steep reverse faults having moderate throw.

At the American Lode the thrust contact between the marble and the underlying schist is better exposed than elsewhere. Gossan deposits are localized along the thrust near steep faults which offset the marble as much as a few hundred feet.

Detailed mapping around the Monarch gossan shows that it may represent a hydrothermal leakage above a horizontal thrust 300 feet helow the surface.

The gold placer on Oregon Creek heads in a linear zone of thrusting several miles long, which contains scattered basic dikes and small plugs. Silicification and dolomitization of the wall rocks and minor sulfide mineralization are present near some of the intrusive basic rocks.

The mineralization associated with the basic rocks in this zone is the probable source of gold in the placer.

During the mapping in 1966 a zone of zinc, 1ead, and minor copper at least 7000 feet 1 ong was discovered along Aurora Creek. Additional work in 1968 indicates that the source of minera $1-$ ization was probably a basic dike that cuts across the deposit in Aurora Creek.

Geochemical work at the American Lode shows only moderate zinc and lead anomalies in parts of the gossan. A line of samples across the Monarch gossan disclosed an anomaly averaging $500 \mathrm{ppm}$ zinc along the east margin over a distance of 600 feet. About 400 geochemical stream sediment and soil samples have been taken in the sinuk map area.

\section{GEOLOGY AND GEOCHEMISTRY NEAR SITHYLEMEKAT LAKE, BETTLES QUADRANGLE, ALASKA}

Gordon Herreid, Mining Geologist

Division of Mines and Geology

An area of 44 square miles was mapped and 140 geochemical samples were taken across a 1 inear belt of intrusive ultramafic rocks extending along the eastern margin of the Koyukuk basin.

Rocks in the area include two belts of typical alpine ultramafic intrusive rocks containing serpentinized peridotite, altered gabbro, and pyroxenite. One belt is located at the margin of the Koyukuk basin. The other is intrusive into schist, 5 miles southeast of the other belt. The remainder of the area is underlain by schist and diabase and an intrusive granite batholith that extends far east of the map area.

Sulfides (pyrite and pyrrhotite) were found in the area only in minute amounts in mafic rocks peripheral to the peridotite. A scattering of geochemical stream sediment samples were anomalous in nicke1, containing as much as $5000 \mathrm{ppm}$. The near lack of pyrite in and around the peridotite suggests a low sulfur content during crystallization, with no early liquid sulfide phase formed. As a result, nickel in the intrusive is probably contained in the silicate minerals. The strong serpentinization indicates a high water content subsequent to crysta11ization. The water could be expected to have moved any sulfides in the ultramafic rock outward into adjacent rocks. In the map area only a few sulfide grains were seen in such locations. 
The presence of tourmaline in some of the granite in the area gives hope of tin deposits in the region. Geochemical samples from several streams in the area are anomalous in tin, containing as much as $70 \mathrm{ppm}$.

\section{URANIUM IN ALASKA}

Gilbert R, Eakins, Mining Geologist

Division of Mines and Geology

This report attempts to summarize all available information on uranium exploration in Alaska. In view of the new uranium boom, it is hoped the information will encourage and guide those who are interested in the search for uranium ore. Much of Alaska remains unexplored.

A map of the State accompanying the report shows 179 areas that have been investigated. A table sumlarizes the geology, mineralization and results of radiometric surveys in each area. The table also includes the quadrangle in which mineralization is located, and appropriate references.

The most interesting localities have been indicated on the map and are briefly discussed. These are: 1) the Bokan Mountain uranium-thorium area on Prince of Wales Island; 2) the Hyder district in southeastern Alaska; 3) the Salmon Bay area on Prince of Wales Island; 4) a zone near the town of Skagway in southeastern Alaska; 5) Nome Creek and Hope Creek in the Fairbanks district; 6) Rampart area on the Yukon River in interior Alaska; 7) the Brooks Mountain and Cape Mountain areas on the Seward Peninsula; and 8) a broad area in northwestern Alaska bordering the Selawik Basin, this area includes the mountains south of Selawik Lake, the Zane Hills, and the copper deposits at Bornite.

Limited investigations of Tertiary sediments for uranium also were conducted by the writer during the summer.

ADDITIONAL GEOCHEMICAL SAMPLING

OF THE WOOU RIVER-TIKCHIK LAKES AREA, SOUTHWESTERN ALASKA

Gilbert R. Eakins, Mining Geologist

Division of Mines and Geology

Geochemical investigations for mercury revealed anomalies in the Wood River Lakes area during the summer of 1967. Follow-up sampling was done in the vicinities of the Red Top Mercury Mine and Lake Aleknagik during the 1968 field season. Laboratory analyses of the samples are not available at this time. The results will be published when the data are received.

\section{A PETRIFIED FOREST ON UNGA ISLAND, ALASKA PENINSULA}

Gilbert R. Eakins, Mining Geologist

Division of Mines and Geology

Petrified logs and stumps large and numerous enough to rival any of those in the well known National and State parks are present over a distance of six miles along the northwest coast of Unga Is Iand. The best specimens are between Unga Spit and Bay Point. Many of the stumps are we 7 exposed in an upright position, and are as much as five or six feet in diameter. At least two stumps are nine feet across. At some locations, dozens of fossil logs are visible on the beach between low and high tide. Most are between 18 inches and four feet in diameter.

A brief report, accompanied by photographs, has been prepared to suggest that the State of Alaska consider creating a State park to protect the coastal area where the best specimens are located. 


\section{GEOLOGY AND GEOCHEMISTRY OF PART OF THE SOLOMON QUADRANGLE, SEWARD PENINSULA, ALASKA}

Roderick R. Asher, Chief Mining Engineer

Division of Mines and Geology

Six weeks were spent mapping 60 square miles in the northwest part of the Solomon $C-5$ quadrangle on the Seward Peninsula, 40 miles east of Nome. The Big Hurrah Mine, the on1y lode gold mine with a production record on the Seward Peninsula, is at the east edge of the map area. Approximately 450 stream sediment samples were taken from all drainages in the quadrangle; consequently stream sampling covers an area larger than the mapped area. In addition, approximately 150 soil and rock samples were taken across the outcrop area of the Hurrah S1ate.

Schist, limestone and slate are the predominant rock types. The schist is dark brownish black to light silvery gray mica schist. Some schist outcrops are calcareous and lenses of recrystaliized 7 imestone are common within the schist. The Hurrah Slate is a dense, black, fissile rock that may be a facies of the schist. The relation between the two rock types is not clear, but at places the contact appears to be gradational. Light gray to white recrystallized limestone forms steep bluffs in large, irregular outcrop patterns. The position of the limestone is probably the result of extensive thrust faulting.

High angle faults are common, but they seem to have had little influence on the localization of metallic minerals. Copper minerals are evident near schist-limestone contacts, where they are localized in silicified zones 10 to 15 feet thick. No economic occurrences of copper were found. Gold occurs in the Hurrah Slate at the Big Hurrah Mine in veins and in silicified shear zones. Antimony-bearing veins are also known in the Hurrah Slate. The Hurrah Slate was sampled extensively and possibly other areas that contain anomalous concentrations of gold or antimony will be indicated when the results are available.

Stream sediments were taken at one quarter mile intervals on streams throughout the quadrangle. The samples were analyzed for 30 elements by spectrographic techniques and for gold, copper, lead and zinc by atomic absorption. The sample data have not been studies completely at this time and no conclusions can be drawn.

\section{A GEOCHEMICAL INVESTIGATION AT CHOLMONDELEY SOUND,} CRAIG QUADRANGLE, SOUTHEASTERN ALASKA*

Theodore Vance, Mining Engineer

Division of Mines and Geology

\section{Summary and Conclusions}

A geochemical investigation was conducted on part of Cholmondeley Sound because of a possible mineralized belt that extends from Dolomi northwestward to Hollis. The area has been extensively prospected in the past, but dense forest cover restricted exploration.

A piece of quartz float assaying $2.92 \%$ copper was found on Divide Head in 1948 by H.M. Fowler, engineer of the Alaska Territorial Department of Mines. He reported the occurrence of numerous quartz stringers, but he found none that contained chalcopyrite.

Sediment samples from al1 streams on Divide Head were collected by the author in 1968. A strong field anomaly was detected in a stream flowing into Cucumber Cove. Heavy metal content increased in strength upstream to a point where the stream issued from the tundra. A search of the surrounding area revealed little because heavy forest and moss obscure outcrops.

It is recommended that further exploration in this area be conducted by extensive soil sampling of the watershed to locate concealed mineralization.

* These reports are not published for distribution, but are available on request. 


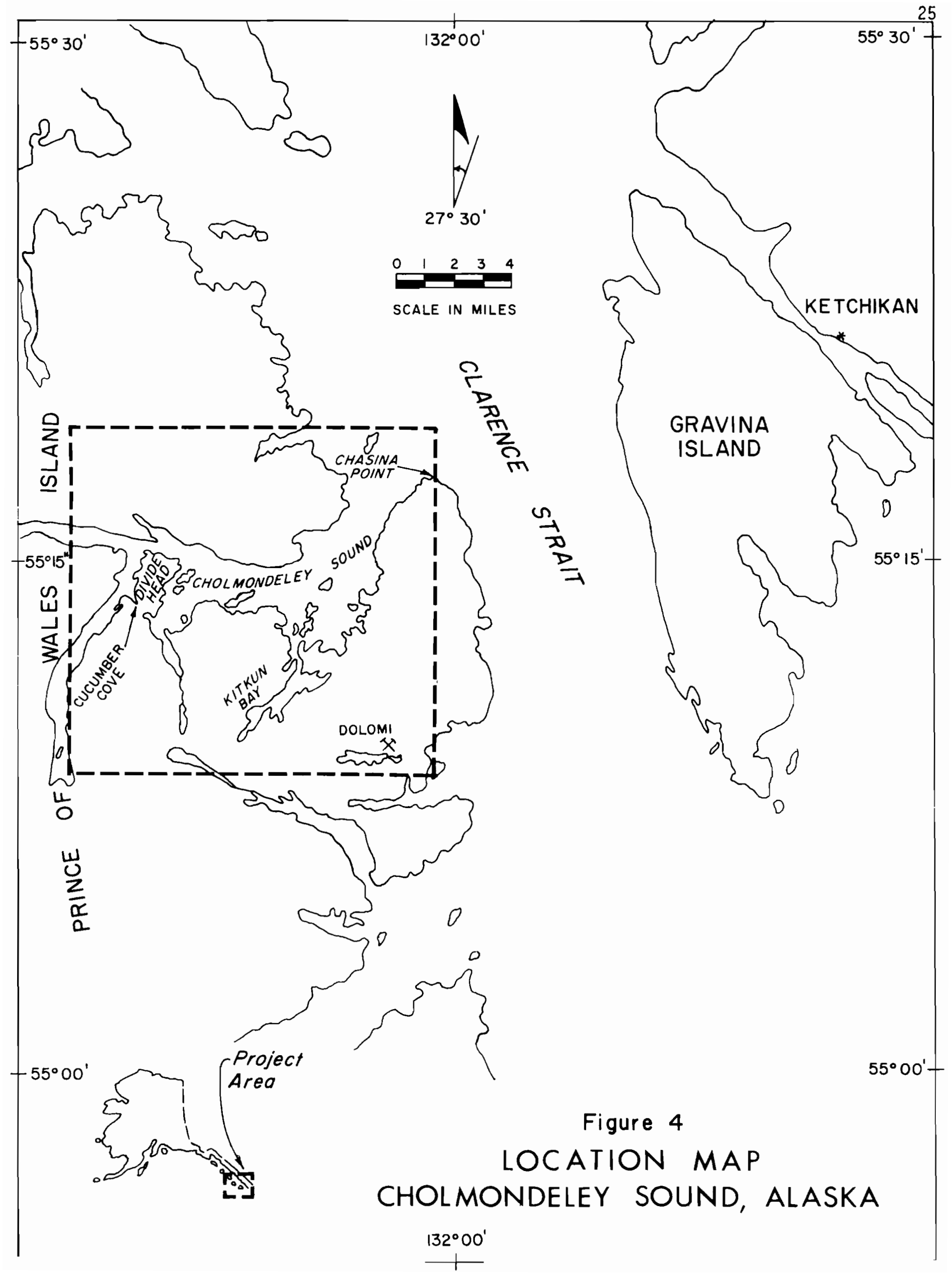


Location and Access

Cholmondeley Sound is a deep ocean inlet on the east side of Prince of Wales Island (fig 4). The Sound may be reached by seaplane from Ketchikan, the nearest city, 20 air miles to the east. The Sound also is accessible by ocean-going boats sufficiently large to navigate Clarence Strait. Kitkun Bay lies on the south side of Cholmondeley Sound and is connected to it by a narrow, rocky passage, which can only be entered at high slack tide. Strong currents with eddies are encountered in the passage at other times because of 20-foot tides.

\section{History}

Although thousands of people passed by on their way north, the mineral deposits of Prince of Wales Island were ignored until 1897. In that year, prospectors returning from the Klondike discovered the copper-iron outcrops at Kasaan. Smelters, constructed at Hadley and Hetta Inlet, operated intermittently until World War I. Bufvers (1967) describes the extensive prospecting around Cholmondeley Sound and Kitkun Bay. Many veins were explored by tunnels and trenches, and much time and effort were expended. However, the average grade of ore proved to be less than $\$ 5.00$ per ton and a11 operations were finally suspended.

\section{Geology}

Condon (1961) described the geology of the area in U.S.G.S. Bulletin 1108-B. The country rock consists of greenstone schists interbedded with limestone and marble. Diorite, granodiorite, and quartz diorite intrude the schists and 1 imestones, which are Paleozoic in age. llajor faults strike northward to northwestward and indicate a complex structural history.

\section{Minera 1 Deposits}

The prospects within the Cholmondeley Sound - Kitkun Bay area are mineralogically complex. Wright and Wright (1908, p 166-171) described these deposits as consisting of copper, lead, zinc, and silver with some free gold. The deposits occur as veins or replacements along shear zones and fissures and are closely related to regional faulting. Those veins which occupy northwestward-striking faults tend to contain the higher values. The gangue minerals are predominantly quartz and calcite.

\section{Geochemistry}

One hundred ninety-six stream sediment samples collected on the south side of Cholmondeley Sound from Divide Head were tested in the field for heavy metals (copper, lead, and zinc) by methods described by Hawkes (1963). The samples were later analyzed in the laboratory and results compared with those obtained in the field. The field and laboratory data did not agree in all samples, which was to be expected because of the inherent problems in field preparation of reagents and procedures. In some watersheds there are known veins in 1 imestone, but stream sediment samples do not contain anomalous values in heavy metals. It is suspected that abundant limestone, being chemically reactive, prevents migration of metallic ions and the development of anomalies.

An anomaly was detected on the west side of Divide Head (fig 4) in a stream flowing into Cucumber Cove. Additional sampling upstream confirmed the anomaly, but a search failed to reveal outcrops in the dense forest.

\section{Selected References}

Condon, W.H., 1961, Geology of the Craig Quadrangle, Alaska: U.S. Geol. Survey Bulletin $1108-\mathrm{B}, 41 \mathrm{p}$

Bufvers, John, 1967, History of mines and prospects, Ketchikan District, prior to 1952 : Alaska Division of Mines and Minerals, $32 \mathrm{p}$

Fowler, H.M., 1948, Report of investigation in the Petersburg-Ketchikan mining precincts: unpublished itinerary report on file at Alaska Division of Mines and Geology, $12 \mathrm{p}$

Hawkes, H.E., 1963, Dithizone field tests: Economic Geology, Vol. 58, p 579-586

Wright, C.W., and Wright, F.E., 1908, The Ketchikan and Wrange11 mining districts, Alaska:

U.S. Geol. Survey Bulletin 347, 202 p 
DIANA LAKES, TALKEETNA MOUNTAINS, SOUTH-CENTRAL ALASKA

Robert E. Anderson, Mining Engineer

Division of Mines and Geology

Geologic mapping and geochemical sampling were done in the Talkeetna Mountains B-5 and B-6 quadrangles between Iron Creek and Sheep River west of Rainbow Lake. In the map area, greenstone, which has been intruded by mafic and granitic rocks, is the predominant rock type. At three places in the area studied, iron oxide is apparent as intensive staining. No copper minerals were identified in the stained zones. A 60 square mile area was studied.

In the area 73 stream sediment samples were taken. Spectrographic analyses of the samples reveal that several contain anomalous amounts of metals, but the data have not been completely evaluated at this time. No previous geologic studies of the map area have been published.

PRELIMINARY GEOLOGIC AND GEOCHEMICAL REPORT ON LITTLE FALLS CREEK, TALKELTNA MOUNTAINS QUADRAINGLE, SOUTH-CENTRAL ALASKA

Robert E. Anderson, Mining Engineer

Division of Mines and Geology

Anomalous amounts of copper were noted in stream sediment samples collected in an area of metasedimentary rocks in the Talkeetna Mountains $\mathrm{C}-3, \mathrm{C}-4, \mathrm{~B}-3$ and $\mathrm{B}-4$ quadrangles. In the area is a bed of pyritic phyllite that is up to 1,000 feet thick; it is exposed for over six miles as a highly iron-stained linear belt. Samples from three streams that cross the phyllite contain anomalous amounts of copper, but there are at least two 1 ines of evidence to suggest that the phyllite is not the source of copper in the stream sediments: 1) Samples that contain anomalous copper were collected both above and below the phyllite, 2) Rock samples collected throughout the area are too low in copper to account for the anomalies. Float, which contains copper-rich vein material, occurs in the area, it probably contributes the anomalous copper to the sediment samples. No copper-bearing veins were found in place, but $90 \%$ of the area is covered by talus.

In the west-central part of the map area, rock samples contain anomalous amounts of gold. The gold concentrations are at least double the amount that would be expected in the rock types sampled.

\section{STIKINAK ISLAND COAL, SOUTHWESTERN ALASKA*}

Robert E. Anderson, Mining Engineer

Division of Mines and Geology

Sitkinak Island, which is off the southwest tip of Kodiak Island in the Trinity Islands C-1 quadrangle, was investigated for commercial coal occurrences between August 14 and August 18, 1968. Several earlier reports discuss coal on Sitkinak Island, one of these reports mentions a 25-foot coal seam southeast of Sitkinak Dome. The authors of that report were unable to reach the probable area of occurrence because of adverse weather.

In 1968 al1 of the areas where continental sediments are reported to crop out on Sitkinak Island were examined to determine if the sediments contain coal seams of economic importance. There are coal seams interbedded with the continental sediments, but no coal seams were found that are thick enough to warrant development or mining. The area around Sitkinak Dome was also investigated, but no coal seams were found. The rocks in the vicinity of the dome are marine sediments. 
BERING RIVER COAL FIELD, SOUTH-CENTRAL ALASKA

Robert E. Anderson, Mining Engineer

Division of Mines and Geology

A four-day examination of coal beds near the head of Carbon Creek in the Bering River Coal Field, Cordova B-1 quadrangle, was made in June 1968. At the time of the visit the Cortella Coal Corporation had an exploration camp in the area. Activity consisted of drilling and trenching along Carbon Ridge.

Several coal beds have been exposed by the exploratory work; the largest bed exposed at the time of the vist is 35 feet thick. Most of the beds strike N40E to N60E and dip steeply northwest. Several faults, which strike northwest, occur northeast of the camp. The coal beds appear to have been offset about 1500 feet northwest by the faults. One normal fault, which strikes northeast and dips 20 to 30 degrees northwest, nearly parallels the bedding in the area and probably intersects the coal beds on the southeast. Consequently the coal beds nearby are limited in depth, as they would terminate along the dip of the fault.

Samples of coal exposed by drilling and trenching have a free swelling index of 2.5 to 4.0. The minimum free swelling index for coking coal is 6.0 .

\section{ANALYSES OF COPPER, LEAD AND ZINC BY ATOMIC ABSORPTION SPECTROGRAPHY* \\ Namok Cho, Assayer Chemist; \\ Pau1 L. Anderson, Laboratory Supervisor \\ Division of Mines and Geology}

A study of the operating parameters, limits of detection, anion interference, and precision and accuracy of the analys is of copper, lead, and zinc by atomic absorption spectrophotometry are described. Defining the limit of detection as 3 above background fluctuation (rather than the more conventional $1 \%$ absorption) and defining precision as the coefficient of variation, the following data were obtained using a hot aqua regia leach of 10 or less grams of sample:

\begin{tabular}{|c|c|c|c|}
\hline Element & $\begin{array}{c}\text { Limit of Detection } \\
\text { (amount in sample) }\end{array}$ & $\begin{array}{c}\text { Coefficient of } \\
\text { Variation }\end{array}$ & $\begin{array}{c}\text { Amount of Element } \\
\text { in the Sample }\end{array}$ \\
\hline $\mathrm{Cu}$ & $1.0 \mathrm{ppm}$ & $3.6 \%$ & $0.25 \mathrm{wt} \%$ \\
$\mathrm{~Pb}$ & $10.0 \mathrm{ppm}$ & $4.2 \%$ & $0.42 \mathrm{wt} \%$ \\
$\mathrm{Zn}$ & $1.0 \mathrm{ppm}$ & $4.2 \%$ & $0.58 \mathrm{wt} \%$ \\
\hline
\end{tabular}

The above precision values include total variation including sampling. The method described is rapid and well suited for the analyses of ores in a geological laboratory in which metallic and matrix elements vary widely.

The method of standard addition as applied to AAS also was investigated. The method is well adapted to analyses of occasional samples and is recommended for those instances.

RAPID RADIOMETRIC ANALYSIS FOR EQUIVALENT URANIUM*

Michael Mitche11 Jr., Geochemical Analyst;

Paul L Anderson, Laboratory Supervisor

Division of Mines and Geology

The laboratory of the Alaska State Division of Mines and Geology is undertaking a program of routinely checking for radioactivity virtually all samples submitted by the public for identification or analytical work. This report describes the routine radioactivity test. It shows that a 5-second test in our lead shielded, end-window, laboratory geiger counter has a 
minimum detection 1 imit of $0.05 \%$ equivalent uranium. (The term equivalent uranium implies that this is a broad spectrum radioactivity test and is not specific for uranium.) A semiquantitative radiometric analysis which has an analytical range between $0.01 \%$ and $2.0 \%$ equivalent uranium, also is described. The semiquantitative analysis uses about 3 grams of powdered rock sample pressed at 12 tons per square inch gage pressure into a 1-1/4 inch pellet. The sample's radioactivity is determined directly from this pellet. The radioactivity from the sample is compared to that from analyzed standards. The precision of the analys is was found to be 10\% to $15 \%$ of the value when taking 100 to 200 total counts, which requires about 1 minute counting time of a $0.1 \%$ analyzed uranium ore sample.

\section{LABORATORY NOTES - SHORT PAPERS}

The following are laboratory notes and short papers dealing with limited subjects prepared by the laboratory staff of the Division of Mines and Geology. These papers are not published for distribution but are available on request.

Laboratory Notes No. 1 - Precision and accuracy of the gold-silver analysis by atomic absorption on a quartz-type rock.

Laboratory Notes No. 2 - Laboratory test of zinc in water and ice.

Laboratory Notes No. 3 - AAS analyses of gold and silver in high antimony samples.

Laboratory Notes No. 4 - Digestion of heavy sulfide ores for AAS analyses.

Laboratory Notes No. 5 - Suggested reporting procedures for atomic absorption silver and gold analyses.

Laboratory Notes No. 6 - Improved mercury analyses by XRS.

Laboratory Notes No. 7 - Molybdenum analyses by atomic spectroscopy.

Laboratory Notes No. 8 - An investigation of the $2833 A^{\circ}$ AAS lead line.

Laboratory Notes No. 9 - Interference by calcium, magnesium, and iron on 1ead, zinc, and silver by AAS analyses. 
SPECIAL REPORTS

RESULTS OF EXPLORATION INQQUIRY

James A. Williams, Director

Robert E. Anderson, Mining Engineer

Division of Mines and Geology

Summary

A letter asking the mining industry to comment on how Alaska can best encourage expansion of exploration for ore deposits was sent to 65 companies. Thirty-eight answers containing comments on one or more subjects in 13 general categories were received.

Twenty-three companies made encouraging statements to the effect that Alaska mineral possibilities are good, the Division is doing valuable work, and/or exploration will increase.

Thirty-six (95\%) of the answers contained constructive suggestions on the need for tax and other incentives, better economics, better transportation, more information and promotional activity, fewer labor problems, relaxed immigration restrictions, more geologic, geochemical, and geophysical work by the State, improved policies and business climate, and/or improved claim staking regulations.

Coming from active companies, these statements are strong and authoritative commentaries on what $\bar{A}$ laska should do if it wishes to attract venture capital to establish an industry to properly utilize the hard mineral resources now lying dormant and provide more jobs and a healthier economy.

\section{General}

Last spring we sent the following letter to 65 of the larger mining and 011 companies who are active in hard mineral exploration in the United States and Canada:

"The State of Alaska needs your advice.

"Though we are expecting the greatest mineral exploration activity in recent years during 1968, it will still be a small fraction of the exploration activity across the line in Yukon Territory and British Columbia. During the past several years both the U.S.G.S. and the Alaska Division of Mines and Minerais have done extensive preliminary geological exploration throughout the State and have discovered many areas of possible ore bodies. However, these have not drawn the interest, which we had naturally hoped for, from the major mining and exploration organizations.

"In your opinion, how can we best encourage expansion of exploration activities by private industry in Alaska?

"Since you know better than anyone what is needed for such encouragement, your opinions will be very helpful to us and much appreciated. Source of the opinions and recommendations will be kept confidential.

"We are looking forward to hearing fron you. Thanks very much."

Of the 65 letters sent out, 42 were answered and one was returned because of a wrong address. Thirty-eight of the 12 answers had comments or suggestions, making a total of $58 \%$ of the companies queried who answered our letter with helpful ideas. A study of the letters received indicates that the results can best be viewed if the comments are grouped into 13 categories under two general headings, 1) Encouragement and 2) Suggestions for Changes. The actual comments are appended, grouped by categories for the reader's benefit (Appendix I). 
A list of the companies written to is also appended (Appendix II). Desiring to contact those in the companies who have the greatest control over company policies and activites, we addressed the letters to company presidents. Many of the letters were referred to lesser authorities for answer, and the answers were weighted accordingly. A comment concerning the economics of exploration or a company's attitude toward a tax situation is of greater importance when coming from a president than from a staff geologist.

For additional information of the reader. Appendix III contains some pertinent Alaska laws in connection with subjects commented on, a few of our own observations, and some quotes from authoritative publications.

The question as stated was nondirective, asking industry: "In your opinion, how can we best encourage expansion of exploration activities by private industry in Alaska?" Since many of the companies made more than one point or suggestion, the total number of comments is greater than the number of letters received. Some of the comments are repeated under different categories. Comments and suggestions were for the most part very well thought out, and we are grateful to those who wrote them for taking the time to do so.

\section{Encouragement}

The question did not ask for encouragulent so it was particularly gratifying to find that 23 companies, or $61 \%$ of those who answered, made one or more favorable statement. Most went on to offer suggestions as we11. Only one company offered a discouraging comment. The encouraging comments were as follows:

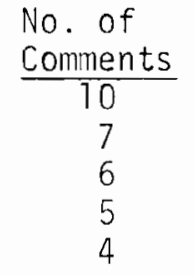

No. of

$\frac{\text { comments }}{10}$

7

5

4
Mineral or discovery

Diveral or discovery potential is good

Division is doing valuable work

Predict that general exploration will increase

Company will continue its present exploration

Company hopes to increase its exploration

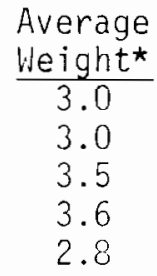

Average

3.0

3.0

3.5

2.8

Since the purpose of this report is to point out the needs of minig, the above favorable comments will not be dwelled upon. One letter pointed out that

"....there are many advantages to be gained in Alaska because it is, in fact a part of the U.S. While many companies are going far afield in search of minerals, many are finding the instability of foreign countries very difficult areas in which to operate."

This is borne out by Zambia's actions in April 1968 when she expropriated and nationalized the American and other copper mines there.

\section{Suggestions for Changes}

A11 but two of the answering companies, i.e., 36 or $95 \%$, made at least one suggestion or comment under this heading, and most had several points to offer. As noted in the tabulation below, the most comments in any category were on taxes, where 23 , or $61 \%$ stated that changes would be helpful.

The order of the following list of categories under this heading is not necessarily representative of importance. They are all important subjects for consideration. Note the weighting of the answers, which was explained earlier.

* Weights were assigned as follows: President 4, Vice President 3, Chief Geologist 2, Staff Geologist 1. 


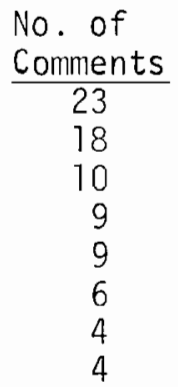

\begin{tabular}{lc}
\multicolumn{1}{c}{ Category } & $\begin{array}{c}\text { Average } \\
\text { Weight }\end{array}$ \\
\cline { 2 - 2 } Tax incentives, advantages, or reductions needed & 3.0 \\
Economics, investments, and incentives & 2.7 \\
More information and promotion needed & 3.1 \\
Better transportation needed & 3.1 \\
Labor & 3.4 \\
More field investigations needed & 3.7 \\
Good policy, stability, and climate needed & 3.7 \\
Improvement of claim staking regulations needed & 3.3
\end{tabular}

Summaries of the comments in the above categories follow. See Appendix I for verbatim quotes from the letters.

Taxes - The largest group of letters points out again and again the effect of taxes on mining, how Canada's tax incentives have accelerated mining there, and how tax incentives should be established in Alaska. One letter specifically recommended the elimination of our mining license tax.

Economics - The need for lower costs and financial assistance by various means is emphasized. Specific suggestions are made to accomplish these things. Subsidies and Securities Exchange Commission problems are discussed.

Information and promotion - The need for more information on opportunities and problems in Alaska is expressed, and we are advised that we should go into promotional activities of various kinds.

Transportation - Attention is called to Canadian road programs which assist mining development, and advice is given that transportation difficulties are holding Alaska back.

Labor - The difficulties of obtaining experienced exploration people in Alaska and of bringing them from elsewhere, and the high cost of Alaskan labor are cited. Cutting labor costs by tax deductions is suggested.

Field investigations - Six companies stress the need for government field work and reports in Alaska. Results of more geologic, geochemical, and geophysical surveys are needed. An aeromagnetic survey of the State should be made.

Policy, stability and climate - Be careful about further increases in oil taxes, develop a conducive exploration climate, don't allow severance taxes, and prevent land withdrawals are the messages received under this heading.

Claim staking regulations - The need for easier acquisition of larger claim blocks and better claim recording facilities is expressed.

\section{Additional Information}

For brevity appendices mentioned above are omitted from the report printed here. Persons interested in further information are invited to write to the Division of Mines and Geology for copies of the appendices. The additional information includes:

1) Specific encouraging comments from companies contacted.

2) Specific suggestions for changes.

3) Names of companies contacted.

4) Observations by Division personne1 and others. 


\section{MINING INCENTIVES}

James A. Williams, Director

Division of Mines and Geology

Division Comments on Programs for Mining

A sound geological basis exists for our belief that Alaska has as much hardrock mineralization per square mile as B.C. and the western mining states. This means that many ore bodies are yet to be discovered, and that we have produced only about 1/60 of our hard mineral potential.

An article from a recent issue of our monthly Mines and Petroleum Bulletin is attached. Perhaps you have already seen it, but if you are interested in the development of mining in Alaska, it is worth a second thought.

The article outlines Canada's successful programs to accelerate discovery and production. Re1atively little exploration is going on in Alaska, and base-metal production here is practically nonexistent. If we want significant Alaska mining production in the near future, we should follow Canada's example. To be sure, these programs will be expensive and are not essential for Alaska's day-to-day operations. But shouldn't we be looking ahead and acting now to help create industry and jobs that will improve our economic base and alleviate our welfare problems in the future?

Keep in mind that mineral exploration itself is an industry which brings in money. Everytime an exploration party loads up with groceries or charters a plane or helicopter for a trip into the bush, new money is being put into circulation. One of the larger parties spent $\$ 600,000$ on Alaskan exploration last summer.

Furthermore, mining production is a labor-intensive industry. It requires men, machinery, and supplies to excavate, crush, concentrate, and transport the ore.

Item 1) in Mr. Price's "pattern of development" is discovery. He doesn't mention it, but extensive geological and aerial geophysical surveys have led to most of the major discoveries in Canada. Aerial geophysical surveys provide the greatest coverage and are the quickest means of stimulating private exploration for minerals. These surveys have been very successful in Canada. We submit that such work is long overdue in Alaska and should be started without further delay. Geological work is proceeding, but much too slowly. In conjunction with the aerial surveys, the assistance programs described by Mr. Price should be instituted for incentive to develop discoveries into producing mines.

The prograris listed by Mr. Price are applicable in northern Canada and are administered by the Canadian federal government. He also mentions tax benefits. We have added information on geological, geochemical, and geophysical surveys. For your easy comparison and further information we have prepared the attached two-page tabulation showing 1) the Canadian federal programs, 2) similar programs on the Canadian provincial level, 3) comparable programs which are, or should be, carried out by the U.S. federal government, and 4) those which are, or should be, carried out by the State of Alaska.

We hope you will think about this. Once the mining industry is well on its way it will continue like the $0 i 1$ industry. But also like the oil industry, incentives are needed to encourage its start. Otherwise most mining companies will continue looking elsewhere.

If you have questions, we would be most pleased to hear from you.

Mining Incentives in Northern Canada

One of the talks given to the recent meeting of the Alaska State Chamber of Commerce at Fairbanks was on the development of minerals in Northern Canada and how this development is being 
facilitated and fostered by the Canadian federal government. The speaker was Edmond E. Price, Consul and Trade Commissioner for Canada, Canadian Consulate, Seattle. In listing the incentive programs, Mr. Price did not include the extensive geological and aerial geophysical surveys initiated and wholly financed by the Canadian federal government. Excerpts from his written text follow:

"The development of Canada's north will follow the historic pattern of development which formed Canada as a nation. It will depend upon:

1) the discovery of desirable mineral in economic quantity,

2) the provision of economic transportation to markets,

3) development of technology to enable economic extraction under condition of severe climate and high transit costs."

"To stimulate development in the North......the Government of Canada has over recent years introduced a number of resource development assistance programs.

"Before outlining these programmes -- which -- additional to the various tax concessions, benefits and write-offs that mining companies enjoy under the Income Tax Act -- I should point out that these programmes apply to Crown land in Northern Canada, which is administered by the federal Department of Indian Affairs and Northern Development."

"The programmes include:

1) The Northern Mineral Exploration Assistance Programme Up to $40 \%$ of an approved exploration programme (including geological, geophysical and geochemical examinations, aerial mapping, surveying, surface examination and drilling) in search of minerals or $0 i 1$ can be provided by the government. If the program is successful, the grant is repayable over a 10 year period commencing when production starts. If unsuccessful, the grant is not repayable.

2) The Prospectors Assistance Program

Provides grants on a first-come first-served basis of up to $\$ 900$ per year to stake an individual prospector. It provides $\$ 30,000$ in each territory to assist prospectors.

3) Northern Roads Program

Provides for assistance or resurface projects up to:

a) $50 \%$ of the construction cost for a tote trail but not to exceed $\$ 20,000$;

b) $50 \%$ of actual road cost for initial access roads to a yearly limit of $\$ 100,000$ if the project is exploratory in nature, and $\$ 500,000$ if the project is primarily development;

c) $2 / 3$ of the cost of construction of permanent access roads, but not exceeding $15 \%$ of actual capital invested by the company prior to commencement of commercial production or exploitation;

d) $100 \%$ of the construction and maintenance costs for resource development and network roads, to link resource-potential areas with established road networks.

4) Northern Resource Airports Program

Provides for financial assistance up to $50 \%$ of the cost of airports in support of exploration operations to a maximum contribution of $\$ 20,000$, and pre-production operations, to a maximum federal contribution of $\$ 100,000$.

5) Economic Feasibility Studies

In some cases, the Federal Government will finance economic feasibility studies of proposed northern priniary production operations.

6) Northern Canada Power Commission A Crown corporation which plans (and in some cases operates) power operation facilities in Northern Canada. It provides power to mining operations in Pine Point and Yellowknife. 
7) Canadian National Railroad

This Crown corporation may also become involved, as it did through the $\$ 80$ million extension of its line from Gringshaw, Alberta, 432 miles north to the Pine Point lead-zinc deposits.

8) Other Assists

These include: financial support for Chambers of Mines; subsidized assay services; strategically located Mining Recorders offices; the provision of serviced lots for sale in "open" toursite developments, etc."

"In the mining field (northern Canada), industry has spent $\$ 260$ million on new mine development in the past 4 - 5 years, supported by $\$ 140$ million in Federal Government expenditure.

"In addition to actual development of new mines - such as Anvi1, Cassiar, New Imperial and Pine Point - - exploration activity is at a $\$ 12$ million annual level, with 36,000 claims recorded in the Yukon and Northwest Territory in 1967 -- up from 5,800 in 1963."

"Value of production (northern Canada) should reach $\$ 150$ million this year." 
Program

Geologic and geochemical

Aerial geophysical, mostly magnetic

Tax benefits

Exploration assistance

Prospector assistance program

\section{Road assistance}

Airport assistance

\section{Canadian Federal}

Very extensive and usually economic-oriented

Very extensive. Many miliions of dollars spent.

$3 \frac{1}{2}$-year exemption from start of production, no capital gains tax, special write-offs.

Up to $40 \%$ matching money for all types of exploration including geological, aerial, drilling, etc.

Up to $\$ 900$ per year per prospector

50 to $100 \%$ participation depending on type of road needed

Up to $50 \%$ participation to a maximum of $\$ 20,000$ if for exploration or $\$ 100,000$ if for production

\section{Provincial}

Extensive, work usually economic-oriented

Frequent

$3 \frac{1}{2}$-year exemption in some provinces.

At least one province provides matching money for exploration.

Several provinces provide similar assistance

B.C. provides partial to $100 \%$ financing, depending on circumstances

Assistance given but not familiar with details

$$
\text { U.S. Federal }
$$

Alaska

Large program. Not usua) ly economic-oriented. May be reduced.

Occasional. Mostly not suited for mining exploration

None ex: pt depletion allowance. Should have 31-year exemption and no capital gains tax like Canadian federal gov't for undeveloped areas.

OME program of partial reimbursement for exploration of specific properties. Funds 1 imited and administration cumbersome. Improvements needed.

None

None. Should provide money for access roads into remote areas for mineral development

None for remote areas
Sma11 economic-oriented. Should be larger program.

None. Should initiate a continuing program.

None. Should abolish Mining License Tax and allow 31-year exemption from corporate profits tax.

None. Could supplement federal OME program to help prospectors explore or develop specific pros pects.

Up to $\$ 2000$ per year per prospector

$50 \%$ reimbursement for roads to promising prospects. Funds presently not available

$50 \%$ reimbursement if road not feasible and airport will help development.

Funds presently not available 
Program

Economic feasibility studies

Power

Railroads

Other assists
Canadian Federal

Occasional financing of feasibility studies of proposed production operations.

Crown corporation provides power to at least some of the producing operations.

Crown corporation built 432-mile railroad to

Pine Point deposits. More railroad in planning stages in Yukon.

Excellent recording and claim location map services, partial financing of chambers of mines for promotion and information assistance.

\section{Provincial}

Don't know if provinces finance studies similar to those described by $\mathrm{Mr}$. Price.

B.C. gov't ready to extend power lines to new operations

Nothing on provincial level within our knowledge.

Excellent claim recording service and claim location maps available. Excellent Chamber of

Mines for promotion and information partially financed by B.C. Gov't.

\section{U.S. Federal}

None. Some engineering and cost studies of

"mode1" operations being made.

Alaska Power Administration is looking for mineral developments as justification for power developments.

Federal should extend Alaska railroad to Seward Peninsula and east to connection with Canadian Nationa 1.

Claim locations should not be required to be filed with U.S. BLM as is proposed because that agency is not ba. sicially working for mineral development.

The records would be for internal use rather than public service.
Alaska

None. State could finance $U$ of $A$ to make studies of specific proposed operations.

None. State should promote power developments and assist with power transmission to developing properties.

State should continue urging federal extension of Alaska Railroad.

Present recording services not sufficient. Complaints are numerous. Good recording service for whole

State could be provided by Div. of $M \& G$ at College. Claim mapping service now. starting but will require some time to cover the State. 
GENERAL

The purpose of the Division of Mines and Geology is to aid and promote the mineral industry in Alaska. To accomplish this purpose Division personnel do everything possible to foster and encourage mineral exploration and new mineral production in the best interest of the State. These activities aid in the development of the basic industries needed so much in Alaska. Much of the work involves first collecting, assembling and interpreting many kinds of data, and then communicating this information to the mining industry and the general pub1ic. The authority and functions of the Division of Mines and Geology as delegated by the Commissioner of Natural Resources are found in Alaska Statutes, Title 27.

The Division of Mines and Geology provides a number of services to the citizens of Alaska. It is responsible for administering the laws pertaining to mineral production and is responsible for mine safety. The analytical laboratory stimulates discoveries and aids bona fide Alaskan prospectors and miners by providing a free assay and mineral identification service. Division personnel do geologic field mapping, geochemical sampling and other functions of a state geologic agency; geologic maps and reports are a principal product of the Division. Technical assistance in the field or in the office on prospecting and mining problems is freely given to those seeking advice. Another function is a continual survey of the mineral resources and operations in the state and the dissemination of this information to those interested in the development of Alaska's mining industry. Although the Division is required by law to foster and promote the best interests of the mining, mineral, and related industries of the State, it also has a responsibility to protect those who invest in these industries. An important phase of the Division's work is the maintenance of an active file or inventory of all known mineral deposits, mining claims, and mining claim owners in the State. The Division of Mines and Geology works closely with the Division of Lands by providing necessary technical help and advice on mineral leasing, prospecting permits, and related matters administered by the Division of Lands.

In 1968 the name was changed from Division of Mines and Minerals to Division of Mines and Geology. The new name more accurately describes the activities and functions of the organization in relation to the total economic development of the State. At the same time the Petroleum Branch of the Division of Mines and Minerals was established as a new Division of the Department of Natural Resources; it is now the Division of 0il and Gas with headquarters at 3001 Porcupine Drive in Anchorage.

After one year the staff of the Division of Mines and Geology is firmly settled in the headquarters at College. The move of the Division was made official by formal opening ceremonies, followed by an "open house" tour of the offices and laboratory faci]ities, on 0ctober 5, 1968.

Throughout the 1968 summer season the Division had six mapping teams in the field. The field staff now includes three engineers and three geologists; when one more geologist is hired the field staff will have its full complement of men. The charts on the following pages present a concise picture of the Division organization, personnel and functions, as well as a summary of work accomplished for 1968. Plans for the 1969 field season are presented on following pages. 
Table 4

Organization, Functions, and Costs - Division of Mines and Geology 1968

DIRECTOR

ADMINISTRATION BRANCH

Administrative Assistant

Secretary

clerk

3 Mining Information Specialists

Draftsman
College
Juneau
Anchorage

Mineral records,

information

Drafting of claim maps

Publishing

Budget, finance, property and personnel
MINING BRANCH

LABORATORY BRANCH

GEOLOGY BRANCH

\section{Authorized Personnel}

Chief Mining Engineer

2 Mining Engineers

3 Summer Assistants
Laboratory Supervisor-X-Ray Mineralogist

Assayer Chemist

Assayer

Clerk Typist

\section{Locations}

Coliege

college

\section{Functions}

Geologic mapping, geochem sampling, prospect exam-

ination and reports

Ore assaying, geochemical and other analyses

Safety inspections, public inquirie.

Mineral identification

Technical advice and help prospectors and miners

Ore testing and research
Geochemical Analyst
Chief Mining Geologist

3 Mining Geologists

Clerk Typist
4 Summer Assistants

Ore province evaluation, geologic mapping, geochem sampling

Economic geology reports and maps

Ore deposit investigations

Costs (FY 68-69 Appropriations)

$\$ 104,900$

$\$ 78,600$

$\$ 74,000$

$\$ 177,700$

Division Total: $\$ \$ 375,200$ 
Table 5

Summary of Work Accomplished By Division Of Mines And Geology In 1968

DIRECTOR

Supervision and Administration of Division

ADMINISTRATION BRANCH

Accounting, budgeting, personnel and property administration; public information, published five professional reports and annual report, petroleum statistics, monthly bulletin (circulation-2300 per month); processed 7,368 claim location notices and 1,092 affidavits and other mining documents, 18,000 claims now on file; assisted 1,400 visitors, answered 2,936 requests for information, distributed or sold 2,059 professional reports, mailed 2,970 information circulars. Held formal opening ceremonies and open house of college facilities.

\section{MINING BRANCH}

Geological and geochemical investigations made in five areas; 70 square miles of geology mapped and 750 stream sediment samples taken; 37 coal mine safety inspections made; administered 19 Prospector Assistanc Programs. $\checkmark$ isited eight prospecting and exploration ites. Represented mining industry and traveled with team of State and Federal investigators studying water pollution associated with mining; conducted survey of mining industry to learn what is needed to encourage more exploration. Studied proposed legislation on conservation and mining reclamation. Prepared draft of information circular on sale and lease of mineral properties. conducted research on coal use, presented talks to professional and civic organizations; visited with numerous prospectors and wrote many letters to persons in the mineral industry

\section{GEOLOGY BRANCH}

Geological and geochemical surveys made in six areas; mapped geology of 124 square miles, collected 596 stream sediment samples. Conducted radiometric surveys in a number of areas to collect data on the occurrence of radioactive ores. Assisted prospectors and visitors, furnished information to industry personnel through discussion and by mail; prepared maps and reports on previous year's investigations.

\section{LABORATORY BRANCH}

Received over 1,500 samples from the public, made determinations ranging from simple identification to $X$-ray spectrograph and diffraction analyses, heavy liquid and magnetic separation, atomic absorption quantitative analyses and fire assays $\mathrm{fc}$ gold, silver, and other noble metals. Did research for broader application of atomic absorption unit. Installed several new instruments that increased the efficiency and latitude of laboratory activities. Performed research on Division geochemical samples for analysis by optical emission spectrograph and atomic absorption. 


\section{DIVISION PROGRAMS FOR 1969}

To provide useful information to prospectors and mining companies interested in exploration, the Division of Mines and Geology selects areas for field work that are likely to contain an ore deposit of economic significance. The end product of such an investigation is a report that includes a discussion of the geology, a geologic map and a presentation of geochemical data that may indicate an exploration target. Thus, as in past years, the areas mentioned below were selected on the basis of economic potential. The amount of field work undertaken in 1969 will depend, in part, upon whether or not the Division has a full complement of field men during 1969. Other factors in the amount of field work that can be accomplished are appropriations received and other duties that the Division may be called upon to do.

\section{Arctic Alaska}

Cosmos Hills near Bornite (copper, gold, "jade"): Geological and geochemical investigations will be undertaken in the northern and western parts of the Cosmos Hills window to supplement similar work begun in the southeastern part of this geological structure in 1968 . The window includes the encouraging copper deposit at Bornite that is being explored by the Bear creek Mining Company. Placer deposits that were formerly worked for gold in the Cosmos Hills are being reworked for the popular "Alaskan jade".

Wiseman-Chandalar region (copper, gold): A new field project involving geological mapping and geochemical sampling in this mineralized region may be undertaken if the Division succeeds in hiring a new qualified mining geologist.

\section{Interior Alaska}

Fortymile Creek (asbestos): A reconnaissance in the Fortymile area near Eagle will be made to check reported occurrences of asbestos in the vicinity. Results will probably be published as an open-file report.

\section{Western Alaska}

Sinuk area (zinc, lead): Geological and geochemical investigations will be continued in critical parts of the Sinuk area on the Seward Peninsula in an effort to complete previous studies of lead-zinc mineralization in this district.

Selawik (uranium): Radiometric surveys in the vicinity of Selawik Lake, near Kotzebue, will be undertaken as part of a continuing program to delineate areas of known or possible uranium mineralization, about which we have had numerous inquiries in recent months.

Casadepaga River (copper, gold): Geological and geochemical investigations will be undertaken in the area north of the Solomon River on the Seward Peninsula. Copper deposits in the region are associated with limestone-schist contacts.

Mount Dixon (copper): Mt. Dixon is on the lower portion of the Casadepaga River, within a belt of copper deposits. A faulted limestone block shows copper mineralization. Mapping and sampling will be done to determine the economic potential of the area.

\section{Southwestern Alaska}

Stepovak Bay (sulfur): In response to numerous inquiries concerning sulfur in Alaska, field investigations will be undertaken in the vicinity of Stepovak Bay near the southwest end of the Alaska Peninsula to study the geologic setting of sulfur deposits in a volcanic environment. 


\section{South-Central Alaska}

Lake Clark area (copper): Geological mapping and geochemical sampling in the vicinity of Lake Clark are planned as part of a study of a belt of copper deposits along the western flank of a large body of intrusive granite west of Cook Inlet.

Yellow Jacket Creek (copper, molybdenum, lead, zinc): An investigation started in 1968 to study gossans in the Talkeetna Mountains by geological and geochemical methods will be continued in 1969.

Iron Creek (silver, copper): Iron Creek is also in the Talkeetna Mountains and possible mineralized areas are indicated there by gossans. These will be investigated as part of the project to investigate gossans in the Talkeetna Mountains.

Tokun Lake (iron): Strong compass deflections are noted by pilots on every flight over an area near Tokun Lake in the Cordova region. A brief aerial magnetometer survey will be conducted followed by a ground magnetometer and geologic study.

\section{Southeastern Alaska}

Prince of Wales Island (copper, uranium, molybdenum, lead): Four field projects in parts of Prince of Wales Island are planned as parts of a continuing program involving investigations of environments interpreted as favorable for copper and uranium mineralization. These investigations are desirable in view of current industry interest in the area.

One of these projects is a geochemical-geological project at Nichols Bay and other bays and inlets in the same general area. A mineralized fault of regional proportions extends from Nichols Bay, northwest through Tah Bay.

Another promising area is in the vicinity of Shakan-Point Baker. Reconnaissance geochemistry and geologic mapping in selected areas may point out important occurrences of copper, lead, and molybdenum.

\section{Other}

In addition to the projects mentioned above, field personnel attempt to contact prospectors and miners by visiting towns and villages throughout the State. Technical help, including prospect examinations, is offered to those seeking advice.

As a supplement to the service offered the mining public through the system of claim data records, the Division plans to draft and publish upon request, claim location maps on published U. S. Geological Survey quadrangles. These sheets will be available to the public at a nominal cost. Plans are also being made to initiate a project that will make unpublished material in the Division's files more readily available to the public.

Research on further applications of the atomic absorption unit to the analysis of a wider variety of geologic materials will be continued in 1969 by laboratory personnel. Progressively more service will be provided to Division field men and the public through the development of rapid and efficient analytical techniques. At present the emphasis is on analysis of Division geochemical samples. 


\section{DIVISION REPORTS}

Reports Published During 1968

Geologic Reports

No. 26 Geological and Geochemical Investigations Southwest of Farewe11, Alaska, by Gordon Herreid, July 1968. Price \$1.00

No. 29 Progress Report on the Geology and Geochemistry of the Sinuk Area, Seward Peninsula, Alaska, by Gordon Herreid, July 1968. Price $\$ 1.00$

\section{Geochemical Reports}

No. 13 Geochemical Investigations of Selected Areas in the Yukon-Tanana Region of Alaska, 1965 and 1966, by W. M. Burand, May 1968. Price $\$ 1.00$

No. 16 A Geochemical Investigation of a Portion of the Fortymile District, Alaska, by W. H. Smith, June 1968. Price $\$ 1.00$

No. 17 A Geochemical Investigation of the Wood River-Tikchik Lakes Area, Southwestern Alaska, by G. R. Eakins, May 1968. Price $\$ 1.00$

Reports To Be Published Soon

The reports listed below are in preparation by the geologists and engineers. The reports are based on the results of field work done in 1968; plans call for release of the reports before the beginning of the 1969 field season. The descriptions given under area refer only to the general location of the study site and are not necessarily the titles that will be used when the report is completed.

Geologic Reports

No.

Area

Author

33 Solomon River, Seward Peninsula, Western Alaska

34 Diana Lakes, Talkeetna Mountains, South-Central Alaska

Asher

Diana Lakes, Talkeetna Mountains, South-Central River, Ray Mountains, Interior Alaska

Sinuk River, Seward Peninsula, Western Alaska

36

Cosmos Hills, Kobuk River, Arctic Alaska

Anderson

Herreid

Herreid

37

Geochemical Reports

18 Iron Creek, Seward Peninsula, Western Alaska

19 Little Falls Creek, Talkeetna Mountains, South-Central Alaska

Asher

Little Falls Creek, Talkeetna Mounta
Tikchik Lakes, Southwestern Alaska

Anderson

20

port

Special Report

Uranium in Alaska

Eakins

Unpublished Reports

In addition to the reports mentioned above, several open-file property examination reports and thineral resources reports were prepared by Division engineers. Included are 1) a three day ceconnaissance of the coal deposits on Sitkinak Island, 2) a brief reconnaissance of the Bernq River coal field, and 3) a number of prospect examination reports. 


\section{PROSPECTOR ASSISTANCE PROGRAM}

The Division of Mines and Geology answered 43 requests for information concerning the Prospector Assistance Program in 1968. Twenty-two of the 43 who requested information responded with applications for assistance. The screening board rejected three applications for assistance, leaving a total of 19 programs. The three applications were rejected because the applicant had a poor record on the program in the past, was in poor physical condition, or lacked experience in comparison to other applicants. Al1 the funds available were encumbered by the first eleven applications to be received and approved. Consequently, eight programs were placed on standby status, whereby the participant accepted the condition that he would be reimbursed only if funds were available after all the earlier programs were paid. Five of the 19 participants completed their programs and submitted the records necessary for reimbursement. Two participants did not spend 30 days in the field and were disqualified, and 12 programs are pending at the time of this writing.

Three of the five participants who submitted programs staked nine new mining claims. The total cost for the five programs was $\$ 14,489.99$ for 772 man days, or $\$ 18.77$ per man day. The reimbursement cost to the State was $\$ 10,888.99$ or $\$ 14.11$ per man day.

Members of the screening board for the 1968 programs were:

\begin{tabular}{|c|c|c|}
\hline Lawrence E. Heiner & $\begin{array}{l}\text { - Mineral Industry Research } \\
\text { of Alaska }\end{array}$ & Laboratory, University \\
\hline Dr. Donald Cook & $\begin{array}{l}\text { College of Earth Sciences } \\
\text { University of Alaska }\end{array}$ & and Mineral Industries, \\
\hline Leo Mark Anthony & $\begin{array}{l}\text { College of Earth Sciences } \\
\text { University of Alaska }\end{array}$ & and Mineral Industries, \\
\hline Theodore Vance & State Mining Engineer & \\
\hline Gilbert R. Eakins & State Mining Geologist & \\
\hline Gordon Herreid & State Mining Geologist & \\
\hline Robert E. Anderson & State Mining Engineer & \\
\hline
\end{tabular}

Table 6 on the following page presents data pertinent to the 1968 Prospector Assistance Programs submitted as of January 13, 1969.

The regulations covering the Prospector Assistance Program provide that submitted programs will be held confidential by the Division for a period of two years. Work is in progress to make programs through 1966 available to the public. 
Table 6

Prospector Assistance Program - 1968

(Based on programs completed as of January 13, 1969)

\begin{tabular}{|c|c|c|c|c|c|c|c|c|c|c|}
\hline \multirow[b]{2}{*}{ Name } & \multirow{2}{*}{$\begin{array}{l}\text { Locality } \\
\text { Prospected }\end{array}$} & \multirow[b]{2}{*}{ 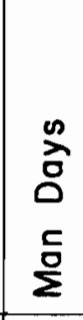 } & \multirow{2}{*}{ 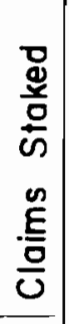 } & \multirow{2}{*}{ 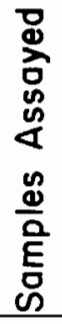 } & \multicolumn{5}{|c|}{ Actual Prospecting Expenditures } & \multirow{2}{*}{$\begin{array}{c}\text { Reimbursed } \\
\text { By } \\
\text { State }\end{array}$} \\
\hline & & & & & Travel & Food & $\begin{array}{c}\text { Equipment } \\
8 \\
\text { Misc. }\end{array}$ & $\begin{array}{c}\text { Total } \\
\text { Expense }\end{array}$ & $\begin{array}{c}\text { Expense } \\
\text { Per } \\
\text { Mon-Day }\end{array}$ & \\
\hline $\begin{array}{l}\text { Ed R. Farrel1; Del } \\
\text { Rainey; Tom Dagley }\end{array}$ & $\begin{array}{l}\text { Manley Hot Springs, } \\
\text { Boulder Creek }\end{array}$ & 456 & 0 & 0 & $\$ 250.00$ & $\$ 606.38$ & $\$ 4.534 .96$ & $\$ 5,391,34$ & $\$ 11.82$ & $\$ 4,000 . n n$ \\
\hline Arthur Smith & $\begin{array}{l}\text { Matanuska River, } \\
\text { Carpenter Creek }\end{array}$ & 41 & 1 & 0 & 149.50 & 216.67 & 193.45 & 559.62 & 13.65 & 419.76 \\
\hline $\begin{array}{l}\text { Ed R. Hudson; } \\
\text { Richard Geraghty }\end{array}$ & Livengood & 102 & 4 & 4 & $-0-$ & 483.32 & $4,452.26$ & $4,935.58$ & 48,39 & $3,751.69$ \\
\hline E. Ronald Anderson & $\begin{array}{l}\text { Brooks Range, Wild } \\
\text { River; Rampart, Minook } \\
\text { River; Indian River, } \\
\text { Utopia Creek; Fairbanks } \\
\text { Pedro Dome }\end{array}$ & 32 & 4 & 1 & 264.00 & 160.00 & 348.00 & 772.00 & 24.13 & 594.00 \\
\hline James A. Wylie & Kuskokwim & 141 & 0 & 0 & $1,009.35$ & ], 096.68 & 725.42 & $2,831.45$ & 20.08 & $2,123.54$ \\
\hline Tota] & & 772 & 9 & 5 & $1,672.85$ & $2,563.05$ & $10,254.09 \mid$ & $14,489.99$ & & $10,888.99$ \\
\hline $\begin{array}{c}\text { Averages per Man } \\
\text { Day }\end{array}$ & & & & & 2.17 & 3.32 & 13.28 & 18.71 & & 14.11 \\
\hline
\end{tabular}


COMPANIES CONSULTANTS MINERS PROSPECTORS

\author{
COMPANIES* \\ (Interested in Alaska Mining Possibilities)
}

Alaskamin Inc.

525 Failing Building

Portland, Oregon

William P. Murray

American Exploration \& Mining Co.

2300 Russ Building

San Francisco, California 94104

Robert G. Garwood

American Smelting \& Refining $C o$.

504, 535 Thur low Street

Vancouver 5, B. C. Canada

Thomas C. Osborne

American Meta 15 Climax (AMAX)

601,535 Thurlow Street

Vancouver 5, B. C. Canada

R. A. Barker

Anaconda American Brass

Brittania Beach, B. C. or

116,744 West Hastings Street

Vancouver $1, B$. C. Canada

Glenn Waterman

Asbestos Corp. (Explorations) Ltd.

814, 837 West Hastings Street

Vancouver $1, B$. C.

Atlantic Refining Co.

Box 59, Anchorage, 99501

or Box 749, Dallas, Texas 75221

Atlas (or Dynasty) Exploration Co.

328,355 Burrard

Vancouver, B. C. Canada

John Brock

Bear Creek Mining Co.

E. 7621 Sprague

Spokane, Washington

David M. Snyder

Bunker Hill Company

P. 0. Box 29

Kellogg, Idaho 83837

Foster Howland

Canex (Placer Development, Ltd.)

800, 1030 West Georgia Street

Vancouver 5, B. C. Canada

A. G. Horton

* Best company contact man listed where known.
Cities Service 0 il Co.

360 K St., Room 302

Anchorage, Alaska 99501

William A. Hul1

Conwest Exploration Co.

901, 675 West Hastings Street

Vancouver 2, B. C.

P. 0. Hachey

Copper Range Exploration Co., Inc.

4401 Wallingford Avenue, $N$.

Seattle, Washington 98103

C. Phillips Purdy, ur.

Cordero Mining Co.

131 University Avenue

Palo Aito, California

J. Eldon Gilbert

Cyprus Mines Corp.

822,510 West Hastings Street

Vancouver 2, B. C. Canada

Donald W. Tully

Duva 1 Corp.

506, 602 West Hastings Street

Vancouver 2, B. C. Canada

Robert Gale

Dynasty Exploration Ltd.

330,355 Burrard Street

Vancouver, B. C.

Eagle Picher Industries, Inc.

Box 910

Miami, Oklahoma

Guggenheim Exploration Co. Inc.

4554 West 6 th Avenue

Vancouver 8 , B. C.

Gavin A. Dirom

Hanna Mining Co.

200, 1200 West Pender Street

Vancouver, B. C. Canada

Alex $G$. Jones

Hecla Mining Co.

1105,900 West Hastings Street

Vancouver, B. C. Canada

Phil Conley 
Homestake Mineral Development Co.

504, 535 Thurlow Street

Vancouver 5, B. C. Canada

L. G. White

Humble $0 i 1$ and Refining Co.

10624 Kensington

Spokane, Washington 99218

Neil N. Campbel1

International Minerals \& Chemical Corp.

5401 0ld Orchard Road

Skokie, I11inois 60076

Peter 0. Sandvik

Internationa 1 Nuclear Corp.

1009 Mendenha 11 Apts.

Juneau. Alaska 99801

Phil R. Holdsworth

International Mine Services Ltd.

Box 1052

Whitehorse, Yukon

John McMullin

J. R. Simplot Co.

Box 2777

Boise, Idaho 83701

George A. McHugh

Kerr McGee $0 i l$ Industries

Kerr McGee Building

Oklahoma City, Oklahoma 73102

Moneta Porcupine Mines Ltd. 420, 475 Howe Street

Vancouver 1, B. C. Canada

B. S. Imric

Newconex Canadian Exploration Ltd.

914, 525 Seymour Street

Vancouver 2, B. C.

Paul W. Richardson

Newnont Exploration, $L t d$.

300 Park Avenue

New York, New York 10022

Robert B. Fulton

Pan American Petroleum Corp.

2601 Security Life Building

Denver, Colorado 80202

Roger Mark 1

Phelps Dodge Corp.

Box 991

Douglas, Arizona

Elmer A. Winter
She 11 Canadian Exploration Co.

815 East Fourth South

Salt Lake City, Utah 84102

She 110 il Co.

100 Bush Street

San Francisco, or 1008 Sixth

Los Angeles, California 90054

Sinclair Oil Co.

Box 521

Tulsa, Oklahoma 74102

Merril Nielson

Springer \& Associates

502, 1200 West Pender Street

Vancouver 1, B. C. Canada

Karl J. Springer

St. Eugene Mining Corp.

(Falconbridge)

504, 1112 West Pender Street

Vancouver 1, B. C. Canada

Alex Sulth

Superior 0 il Co.

1 East First Street

Reno, Nevada

Tennessee Corp.

61 Broadway

New York, New York

Texas Gulf Sulphur Co.

701,1281 West Georgia Street

Vancouver 5, B. C. Canada

J. Russe11 Lowdon

Utah Construction \& Mining Co.

718 , 510 West llastings Street

Vancouver 2, B. C. Canada

E. S. Rugg, G. A. Noel

U. S. Steel Corp.

Box 510

Provo, Utah

J. K. Hayes

Union 0 il Company of California

2805 Denali Street

Anchorage, Alaska 99503

Gary F. Player

U. S. Smelting Refining \& Mining Co.

Box 1170

Fairbanks, Alaska 99701 or

235 East 42nd Street

New York, New York 10017 
Vitro Minerals Company

90 Park Avenue

New York, New York 10016

E. G. Hotchkiss, or 600 West 33rd South St.

Salt Lake City, Utan 84115

Cecil Smith
White Pass \& Yukon Route

1318,510 West Hastings Street

Vancouver 2, B. C.

Charles J. Brown

CONSULTANTS

(Available for Work in Alaska)

Alaska Drilling \& Construction Co.

David McCrillus

Box 742

Ward Cove, Alaska

Alaska Geological Consultants

2227 Spenard Road

Anchorage, Alaska 99503

Alaska Minera] Lab (Assaying)

2229 Spenard Road

Anchorage, Alaska 99503

A Trenco

Clyde Wethere 11

2805 Bering

Anchorage, Alaska

Eski 1 Anderson

309 Radio Central Building

Spokane, Washington 99204

Earl H. Beistline

Box 148

College, Alaska 99701

Douglas Colp

1101 Gillam Way

Fairbanks, Alaska 9970]

Donald J. Cook

Box 5-93

College, Alaska 99701

Arthur F. Daily

488 Fairbanks Avenue

Oakland, California 94610

Dickinson-0swald \& Assoc's (mineral surveying)

433 West 9th Avenue

Anchorage, Alaska 99504

Lawrence E. Heiner

Box 5-433

College, Alaska 99701
Charles F. Herbert

Box 1464

Anchorage, Alaska 99501

Wallace McGregor

Box 6351

Salt Lake City, Utah 84106

George A. Moerlein

Box 40, Star Route A

Anchorage, Alaska 99502

William A. O'Neill

505-8th Avenue

Anchorage, Alaska

Dan Renshaw

1329 "S" Street

Anchorage, Alaska 99501

A. L. Renshaw, Jr.

1850 Wickersham Drive

Anchorage, Alaska 99502

Robert H. Saunders

P. 0. Box 1801

Fairbanks, Alaska 99701

R. H. Seraphim

427-470 Granvi11e

Vancouver 2, B. C. Canada

Ruth A. M. Schmidt

1040 C Street

Anchorage, Alaska 99501

Starkey A. Wilson

852 Wilson Building

Dallas, Texas

Ernest Wolff

320 East Plum Street

Fort Collins, Colorado 80521

James R. Wylie

Box 208

Aptos, California 95003 
MINERS AND PROSPECTORS ACTIVE DURING 1968

Mining and Prospecting Other Than Coal

\begin{tabular}{|c|c|c|c|}
\hline Name and Address & $\begin{array}{l}\text { Location of Mines \& } \\
\text { Recording Districts }\end{array}$ & $\begin{array}{c}\text { Approx. } \\
\text { Crew }\end{array}$ & Type of Operation \\
\hline $\begin{array}{l}\text { Agoff, S. E. } \\
\text { Flat }\end{array}$ & $\begin{array}{l}\text { Prince Creek } \\
\text { Mt. Mckinley }\end{array}$ & 2 & Nonfloat \\
\hline $\begin{array}{l}\text { Alaska Barite Co. } \\
1112 \text { So. Cushman } \\
\text { Tacoilla, Washington }\end{array}$ & $\begin{array}{l}\text { Castle Island } \\
\text { Petersburg }\end{array}$ & 20 & $\begin{array}{l}\text { Open pit mine } \\
\text { Barite production }\end{array}$ \\
\hline $\begin{array}{l}\text { Alaska Exploration Co. } \\
5066 \text { th Avenue } \\
\text { Anchorage }\end{array}$ & $\begin{array}{l}\text { Norton Sound } \\
\text { Cape Nome }\end{array}$ & 1 & Offshore prospecting \\
\hline $\begin{array}{l}\text { Alaskallin } \\
525 \text { Failing B1dg. } \\
\text { Portland, Oregon }\end{array}$ & $\begin{array}{l}\text { Post River } \\
\text { Bowser Creek }\end{array}$ & 12 & Exploration \\
\hline $\begin{array}{l}\text { Alaska Mines \& Minerals, Inc. } \\
\text { Ray Wolf } \\
\text { Box } 422 \\
\text { Anchorage }\end{array}$ & $\begin{array}{l}\text { Red Devil Mine } \\
\text { Kuskokwim }\end{array}$ & 1 & Development \\
\hline $\begin{array}{l}\text { Alaska Red Top Mine, Inc. } \\
\text { C. T. Rasmussen } \\
7933 \text { Jewell Lake Road } \\
\text { Anchorage }\end{array}$ & $\begin{array}{l}\text { Marsh Mountain } \\
\text { Bristol Bay }\end{array}$ & 2 & Prospecting \\
\hline $\begin{array}{l}\text { Alaska Yukon Minerals Co. } \\
111 \text { East } 5 \text { th Avenue } \\
\text { Anchorage }\end{array}$ & $\begin{array}{l}\text { Copper River region } \\
\text { Chitina }\end{array}$ & 2 & Prospecting \\
\hline $\begin{array}{l}\text { A]max, Ted } \\
\text { Dil Tinghall }\end{array}$ & $\begin{array}{l}\text { Tikchik Lakes } \\
\text { Dillingham }\end{array}$ & 1 & Prospecting \\
\hline $\begin{array}{l}\text { Alvenco (Alminex) } \\
\text { Clyde Wetherell } \\
2805 \text { Bering } \\
\text { Anchorage }\end{array}$ & $\begin{array}{l}\text { Alaska general } \\
\text { Several }\end{array}$ & 3 & Prospecting \\
\hline $\begin{array}{l}\text { Amax Exploration Inc. } \\
601,535 \text { Thurlow Street } \\
\text { Vancouver, B.C. }\end{array}$ & $\begin{array}{l}\text { Alaska general } \\
\text { Several }\end{array}$ & 1 & Investigations \\
\hline $\begin{array}{l}\text { Amerada Petroleum } \\
\text { P.0. Box } 2040 \\
\text { Tulsa, Oklahoma }\end{array}$ & $\begin{array}{l}\text { Bering Sea } \\
\text { Cape Nome }\end{array}$ & 1 & Offshore prospecting \\
\hline $\begin{array}{l}\text { American Exploration \& Mining Co. } \\
\text { Russ Building } \\
\text { San Francisco, California }\end{array}$ & $\begin{array}{l}\text { Alaska general } \\
\text { Several }\end{array}$ & 2 & Investigations \\
\hline
\end{tabular}


American Smelting \& Refining Co. Room 504, Phillips Building 535 Thurlow Street Vancouver, B. C.

Ames, Robert 12205 th

Fairbanks

Anderson, E. Ronald Aniak

Anderson, Red

Manley Hot Springs

Asbestos Corp. Ltd.

814 - 837 W. Hastings

Vancouver, B. C.

\section{Au Limited Henry Warner Box 674 \\ College}

Ballard, John D. Box 920

Sitka

Basey, Bill \& Martin, Lloyd Box 1173

Ketchikan

Bear Creek Mining Co.

E. 7621 Sprague

Spokane, Washington

Berg, Rhinehart

Kobuk

Blair, Boyd

320 Lakeview Trailer Court

Fairbanks

Bliss, Patrick J. \& Sons

129 E. 11th

Anchorage

Boedecker, Bill \& Joines, Evert Hollis

Boese, Earl

Wiseman

Bonanza Gold, Inc.

E. 15 Walton

Spokane, Washington
Alaska general

Several

6

Property exploration

Ready Bullion Creek

Fairbanks

Pedro Dome

Fairbanks

Glen Gulch

Manley Hot Springs

Alaska general

Severa]

Porcupine Creek

Fairbanks

Chichagof Is land

Sitka

George Inlet

Ketchikan

Kobuk region \& Alaska Range

Several

Kugruk

Fairhaven

Eva Creek

Fairbanks

Ungalik Creek

Cape Nome

40

Holl is

Ketchikan

Linda Creek

Fairbanks

Prince of Wales Island Ketchikan
3

2

Placer development

Drilling \& Recon

Smal1 scale hand

Prospecting

2 Nonfloat

Exploration

Prospecting

2 Lode

4 Exploration

2 Gold lode development

$3 \quad$ Nonfloat

$2 \quad$ Prospecting

2 Nonfloat

4 Development 
Bonne11, Frank

1057 W. 80th Street

Los Angeles, California

Bookwalter, Vern

Nome

Bradley, Carl

Wrange11

Brockway, John T.

1737 Glacjer Avenue

Juneau

Bruce, Farrell

Box 10149 Klatt Station

Anchorage

Bunker Hill

Box 29

Ke1logg, Idaho

Burdick, Gordon

Mccarthy

Burns, John

Fairbanks

Busty Belle Mine

Tury Anderson \& Associates

101 E Street, Hamilton Acres

Fairbanks

Cambridge Mining Corp. Ltd.

1130 Bay Street

Toronto, Canada

Canyon Creek Mining Co.

Jens Kvamme \& Sons

Akiak

Casto, Steve

$33 \mathrm{Mile}$

Haines

Chandalar Gold Mining Co.

Box 1332

Fairbanks

Chaplin, Larry D.

Box 1455

Juneau

Coben, Daniel \& Monroe, Gilbert

Fairbanks
Kantishna District

Fairbanks

Buster Creek

Cape Nonie

S. E. Alaska

Several

Baker Peak

sitka

Chicken

Fairbanks

Alaska general

Several

McCarthy

McCarthy

Poker Creek (40-mile)

Fairbanks

Fairbanks

Fairbanks

Seal Cove

Ketchikan

Canyon Creek

kuskokwim

Porcupine Creek

Haines

Chandalar District

Fairbanks

S. E. Alaska

Boulder Creek

Manley Hot Springs
2 Nonfloat

Lode prospecting

$1 \quad$ Prospecting

1 Copper development

1 Lead-silver development

1 Investigations

Copper development

Nonfloat

Lode development

5 Drilling

$4 \quad$ Hydraulic

1 Small scale hand

$10 \quad$ Nonfloat and mill

Construction

2 Peat investigation

$2 \quad$ Placer prospecting 


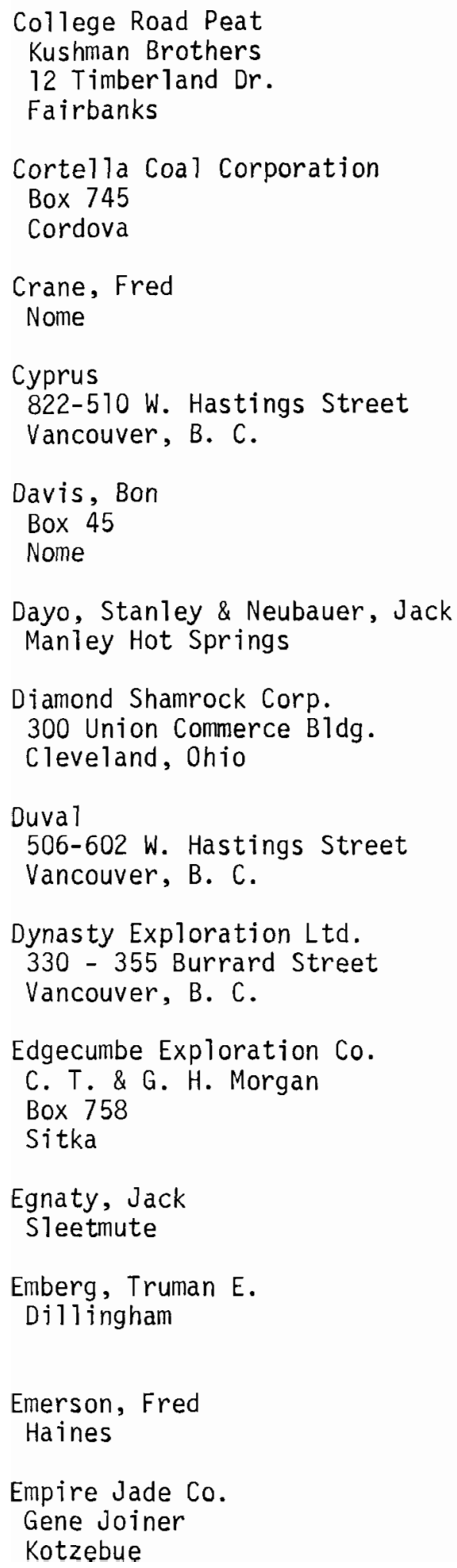

College Road
Fairbanks

Bering Glacier Field, 8 Coal development Carbon Creek

Steep Creek

Cape Nome

Alaska general

Several

Eagle Creek

Cape Nome

Cooney Creek

Manley Hot Springs

Cinnabar Creek

Mt. Mckinley

Orange Hill

Fairbanks

McLean Arm

Ketchikan

Silver Bay

Sitka

George River

Kuskokwim

Egegik Bay to

Ugashik Bay

Alaska Peninsula

Porcupine Creek

Haines

Jade Creek

Noatak-Kobuk
10 Drilling copper prospect

8

Exploration

2

Gold lode maintenance

1 Exploration

$4 \quad$ Beach sand prospecting

1 Small scale hand

$1 \quad$ Jade recovery \& cutting 
Falconbridge (St. Eugene Mining Co.) 504, 1112 West Pender Street

Vancouver, B. C.

Farre11, Ed \& Rainey, Del

Fairbanks

Ferguson, Bi11

Box 985

Fairbanks

Foster, Willie

Nome

Fullerton Brothers

Flat

Gilbertson, George

314 Charles Street

Fairbanks

Global Marine

811 W. 7 th St., Room 402

Los Angeles, California

Goodnews Bay Mining Co. 422 White Building, Seattle

or Platinum

Guggenheim Exploration Co. Inc. G. A. Dirom

4554 West Sixth Avenue

Vancouver, B. C.

Hanna Mining Corp.

1300 Leader Building

Cleveland, Ohio

Hansen, Burnett F. Eagle

Hapeman, Fred

Chicken

Hassel Mining Co.

Harold Hassel

Box 1071

Fairbanks

Hawkins, W. A.; Eichner, Ken; and Lillie, Angus

Ketchikan

Hecla

1105-900 W. Hastings Street

Vancouver, B. C.
Central Alaska

Severa 1

Boulder Creek

Manley Hot Springs

Ester Dome

Fairbanks

Hannum Creek

Fairhaven

Willow Creek

Mt. McKinley

Dan Creek

McCarthy

S. E. Alaska

Juneau

Salmon River \& Tribs. $\quad 40$ Bethel

Alaska general

Several

Alaska general

Several

7

Ben Creek

Fairbanks

Fortyfive Pup (40-mile)

Fairbanks

Ready Bullion Creek

Fairbanks

S. E. Alaska

Several

Alaska general

Several
1

Investigations

Exploration

2

Prospecting

Nonfloat \& lode

prospecting

Nonfloat

Nonfloat

Offshore prospecting

Platinum dredge

Nonf loat

Nonf loat

Nonfloat

1 Investigations 


\begin{tabular}{|c|c|c|c|}
\hline $\begin{array}{l}\text { Heiner, Larry } \\
\text { Petersburg }\end{array}$ & $\begin{array}{l}\text { Southeastern Alaska } \\
\text { Several }\end{array}$ & 1 & Prospecting \\
\hline $\begin{array}{l}\text { Hibberd, Bill } \\
1723 \mathrm{~A} \text {. Tongass } \\
\text { Ketchikan, Alaska }\end{array}$ & $\begin{array}{l}\text { S. E. Alaska } \\
\text { Several }\end{array}$ & 1 & Prospecting \\
\hline $\begin{array}{l}\text { Hi11, Howard } \\
221 \text { 2nd Avenue } \\
\text { Fairbanks }\end{array}$ & $\begin{array}{l}\text { Platte Creek } \\
\text { Nenana }\end{array}$ & 2 & Nonf loat \\
\hline $\begin{array}{l}\text { Hogendorn, Jack } \\
\text { Deering }\end{array}$ & $\begin{array}{l}\text { Inmachuck River } \\
\text { Fairhaven }\end{array}$ & 1 & Hydraulic \\
\hline $\begin{array}{l}\text { Holloway, Dorr \& Rehard, Robert } \\
\text { Red Devil }\end{array}$ & $\begin{array}{l}\text { Kolmakof Property } \\
\text { Kuskokwiml }\end{array}$ & 2 & $\begin{array}{l}\text { Mercury expioration \& } \\
\text { drilling }\end{array}$ \\
\hline $\begin{array}{l}\text { Homestake Mineral Development Co. } \\
304,535 \text { Thurlow Street } \\
\text { Vancouver, B. C. }\end{array}$ & $\begin{array}{l}\text { Alaska General } \\
\text { Several }\end{array}$ & 1 & Investigations \\
\hline $\begin{array}{l}\text { Hudson, Edwin \& Wittrock, Wayne } \\
817 \text { Lakeview Trailer Court } \\
\text { Fairbanks }\end{array}$ & $\begin{array}{l}\text { Livengood } \\
\text { Fairbanks }\end{array}$ & 3 & Prospecting \\
\hline $\begin{array}{l}\text { Huff, J. W. } \\
\text { Box } 837 \\
\text { Ward Cove }\end{array}$ & $\begin{array}{l}\text { Groundhog Basin } \\
\text { Wrange } 11\end{array}$ & 20 & Prospecting \\
\hline $\begin{array}{l}\text { Humble } 0 i 1 \text { \& Refining Co. } \\
\text { P. 0. Box } 120 \\
\text { Denver, Colorado }\end{array}$ & $\begin{array}{l}\text { S. E. Alaska } \\
\text { General }\end{array}$ & 5 & Recon exploration \\
\hline $\begin{array}{l}\text { International Mineral \& } \\
\text { Chemical Corp. } \\
\text { 01d Orchard Road } \\
\text { Skokie, I11inois }\end{array}$ & $\begin{array}{l}\text { Alaska General } \\
\text { Several }\end{array}$ & 1 & Investigations \\
\hline $\begin{array}{l}\text { International Nuclear Corp. } \\
\text { Phil R. Holdsworth } \\
1009 \text { Mendenhall Apts. } \\
\text { Juneau }\end{array}$ & $\begin{array}{l}\text { S. E. Alaska } \\
\text { Several }\end{array}$ & 1 & Investigations \\
\hline $\begin{array}{l}\text { International Mine Services, Ltd. } \\
\text { Box } 1052 \\
\text { Whitehorse }\end{array}$ & $\begin{array}{l}\text { A 1aska General } \\
\text { Several }\end{array}$ & 1 & Investigations \\
\hline Johnstone, Jack & $\begin{array}{l}\text { Prince of wales Island } \\
\text { Ketchikan }\end{array}$ & 2 & Prospecting \\
\hline $\begin{array}{l}\text { Jurgeleit, Art \& Jo } \\
\text { Haines }\end{array}$ & $\begin{array}{l}\text { Porcupine Creek } \\
\text { Haines }\end{array}$ & 1 & Small scale hand \\
\hline $\begin{array}{l}\text { Kiwalik Mining Co. } \\
\text { Nome }\end{array}$ & $\begin{array}{l}\text { Kiwalik } \\
\text { Cape Nome }\end{array}$ & 2 & Moving dredge \\
\hline
\end{tabular}




\begin{tabular}{|c|c|c|c|}
\hline $\begin{array}{l}\text { Kloss, Herman } \\
\text { K \& D Lode } \\
\text { Sunset Cove }\end{array}$ & $\begin{array}{l}\text { Sunset Cove } \\
\text { Juneau }\end{array}$ & 1 & Prospecting \\
\hline $\begin{array}{l}\text { Lanning, Tony } \\
\text { Manley Hot Springs }\end{array}$ & $\begin{array}{l}\text { Thanksgiving Creek } \\
\text { Manley Hot Springs }\end{array}$ & 1 & Nonfloat \\
\hline $\begin{array}{l}\text { Larsen, Clifford } \\
\text { P. 0. Box } 1875 \\
\text { Fairbanks }\end{array}$ & $\begin{array}{l}\text { McKinley Park } \\
\text { Nenana }\end{array}$ & & Prospecting \\
\hline $\begin{array}{l}\text { Larson, Ken } \\
\text { Box } 1388 \\
\text { Ketchikan }\end{array}$ & $\begin{array}{l}\text { S. E. Alaska } \\
\text { Several }\end{array}$ & 1 & Prospecting \\
\hline $\begin{array}{l}\text { Lee, Richard } \\
\text { Nome }\end{array}$ & $\begin{array}{l}\text { Tin City } \\
\text { Cape Nome }\end{array}$ & 13 & Nonfloat \\
\hline $\begin{array}{l}\text { Leonard, Harry B. } \\
\text { A. C. Mining Co. } \\
\text { Wiseman }\end{array}$ & $\begin{array}{l}\text { Vermont Creek } \\
\text { Fairbanks }\end{array}$ & 1 & Small scale hand \\
\hline $\begin{array}{l}\text { Lindfors, Hugo } \\
\text { Nome }\end{array}$ & $\begin{array}{l}\text { Rocky Mtn. Creek } \\
\text { Cape Nome }\end{array}$ & 1 & Development \\
\hline $\begin{array}{l}\text { Lucky Seven Mining Co. } \\
\text { Walter E. Roman } \\
\text { Box } 141 \\
\text { Fairbanks }\end{array}$ & $\begin{array}{l}\text { Fish Creek } \\
\text { Fairbanks }\end{array}$ & 7 & Nonfloat \\
\hline $\begin{array}{l}\text { Lyman, Robert } \\
\text { Lyman Mining Co. } \\
\text { Red Devi1 }\end{array}$ & $\begin{array}{l}\text { White Mountain } \\
\text { Kuskokwim }\end{array}$ & 4 & Cinnabar production \\
\hline $\begin{array}{l}\text { McCanse, A } \\
\text { Ronde Valley Lumber Company } \\
\text { P. 0. Box } 608 \\
\text { Union, Oregon }\end{array}$ & $\begin{array}{l}\text { Klery Creek } \\
\text { Noatak-Kobuk }\end{array}$ & 4 & Dredge \\
\hline $\begin{array}{l}\text { McCay, Alan } \\
\text { Box } 513 \\
\text { Wrangel1 }\end{array}$ & $\begin{array}{l}\text { S. E. Alaska } \\
\text { Several }\end{array}$ & 2 & Prospecting \\
\hline $\begin{array}{l}\text { McGee, L. } \\
836 \text { Lindley way } \\
\text { Reno, Nevada }\end{array}$ & $\begin{array}{l}\text { Tofty } \\
\text { Manley Hot springs }\end{array}$ & 5 & Nonfloat \\
\hline $\begin{array}{l}\text { McGil1, Fred } \\
\text { Petersburg }\end{array}$ & $\begin{array}{l}\text { Admiralty Island } \\
\text { Petersburg }\end{array}$ & 1 & Prospecting \\
\hline $\begin{array}{l}\text { MCGi11, Robert H. } \\
\text { Moser Bay }\end{array}$ & $\begin{array}{l}\text { Lower Cash Inlet } \\
\text { Seldovia }\end{array}$ & 1 & Prospecting \\
\hline $\begin{array}{l}\text { McGregor, Wallace } \\
\text { Box 6351 } \\
\text { Salt Lake City, Utah }\end{array}$ & $\begin{array}{l}\text { Alaska General } \\
\text { Several }\end{array}$ & 7 & Recon exploration \\
\hline
\end{tabular}


Mardis, James E.

General Delivery

Anchorage

Marvel Creek Mining Co.

Awe, Charles

Aniak

Meldrum, Billy
Chicken

Miettunen, Ray

332 Dunbar

Fairbanks

Mills, Levy A.

Kotzebue

Mineral Basin Mining Corp.

Moa, Arthur

Box 126

Hyder

Miscovich, Andrew

779 8th

Fairbanks

Miscovich, John

Otter Dredging Co.

Flat

Moore, Norman

326 Baranof Street

Fairbanks

and

Dohney, Edward

Box 604

College

Munz, Wil1iam

Nome

Newlun, 0. H.

Box 623

Ketchikan

Newmont Exploration Ltd.

300 Park Avenue

New York

North American Dredge Co. John Stevens

Flat

Northland Mines

Charles W. Monroe

Box 876, Big Delta
Glacier Bay

Juneau

Marvel Creek

Bethe1

Chicken Creek (40-mile) 1

Fairbanks

Alder Creek (40-mile) 1 Nonfloat

Fairbanks

Noatak River

Noatak-Kobuk

Mt. View Property

Ketchikan

Porcupine Creek

Fairbanks

Otter Creek

Mt. McKinley

Chistochena River

Chitina

Daht Creek

Noatak-Kobuk

Prince of Wales Island

Ketchikan

Alaska General

Several

30

Otter Creek

Mt. McKinley

Nowitna

Mt. McKinley
Prospecting

Dredge

Stripping

Prospecting

$2 \quad$ Lode development

2 Nonfloat

2 Nonfloat

2 Lode gold exploration 
Occidental Minerals

0'Carrol1, Michael J.

14615 - 25th S. W.

Seattle, Washington

Ocean Science \& Engineering

4905 Del Ray Avenue

Washington, D. C.

Olive Creek Mines

Carl Parker

Box 552

Fairbanks

01son, Henry T. "Tiger"

Taku Harbor

0tt, Martin $H$.

332 N. Boundary

Fairbanks

Pacific Construction Co.

Lundgren, Jim

707 Steese

Fairbanks

Pannick, Harry General Delivery

Fairbanks

Parker, Albert

Box 289

Juneau

Parker, Fred

Deering

Pedersen, Steve

Council

Phelps Dodge Corp.

Box 991

Douglas, Arizona

Pieper, Paul

Box 1294

Ketchikan

Price, Stan

Box 1262

Juneau

Prospector John

Box 271

Skagway
Bering Sea

Cape Nome

Long Creek

Nula to

Norton Sound

Cape Nome

Amy Creek

Fairbanks

Juneau \& Admiralty

Districts

Chicago Creek

Manley Hot Springs

Steamboat Creek

Fairbanks

Flume Creek

Fairbanks

Glacier Bay

Juneau

Inmachuck River

Fairhaven

Ophir Creek

Cape Nome

Alaska general

Severa 1

S. E. Alaska

Several

Admiralty Island

Juneau

Skagway

Skagway
Offshore prospecting

3

Nonfloat

9

offshore prospecting

$4 \quad$ Nonfloat

$1 \quad$ Prospecting

$1 \quad$ Nonfloat

$3 \quad$ Prospecting

2 Nonfloat

2 Gold lode maintenance

$4 \quad$ Nonfloat

2 Dredge

1 Investigations

$1 \quad$ Prospecting

$1 \quad$ Prospecting

1 Small scale hand 
Radovan, Martin

McCarthy

Rainbow Mining Co.

Ed Dalton

Box 990

North Pole

Rambaud, John

Chicken

Redstone Mining Co.

Carl Heflinger

409 Clara Street

Fairbanks

Reed Mineral Exp1. Co.

William Ehrich

Box 485

Rosemont, $\mathrm{Pa}$.

Rhode Island Creek Mines

A. W. Pringle

Manley Hot Springs

R. S. Richards \& Associates Box 1817

Anchorage

Roberts, Don 0.

Box 1700

Fairbanks

Robinson, George F.

Chicken

Ross, Don

Box 2307

Ketchikan

Rowan Drilling Company, Inc. 3023 Humble Building

Houston, Texas

Ruby Mining Co.

Al Kangus

Ruby

Rusaw, Max

Route 2, Box 371

Nampa, Idaho

Shel1-Asarco

She11 B1dg; 100 Bush Street

San Francisco, California
Glacjer Creek

McCarthy

Fairbanks

Fairbanks

Fortymile River

Fairbanks

Livengood Creek

Fairbanks

Michican Creek-Wild River

Fairbanks

Rhode Island Creek

Manley Hot Springs

N. Fork Kashwitna River 3 \& Alaska Peninsula area Severa]

Brooks Range

Noatak-Kobuk

Wade Creek (40-mile)

Fairbanks

S. E. Alaska

Bering Sea

Cape Nome

Long Creek

Nulato

Rusaw Creek

Palmer

Bering Sea

Cape Nome
Copper lode prospecting

Prospecting

Nonfloat

$4 \quad$ Nonfloat

4

Lead, silver, gold lode exploration

Copper, iron \& gold prospecting

Prospecting

Stripping

Prospecting

10 offshore prospecting

2 Nonfloat

$1 \quad$ Prospecting

10

Offshore prospecting 


\begin{tabular}{|c|c|c|c|}
\hline $\begin{array}{l}\text { Sinclair } 0 \text { il Co. } \\
\text { Box } 584 \\
\text { Anchorage }\end{array}$ & $\begin{array}{l}\text { Alaska Peninsula } \\
\text { Several }\end{array}$ & 6 & Prospecting \\
\hline $\begin{array}{l}\text { Sirilo, Julius } \\
\text { Box } 625 \\
\text { Bethe1 }\end{array}$ & $\begin{array}{l}\text { Aniak district } \\
\text { Kuskokwim }\end{array}$ & 1 & Prospecting \\
\hline $\begin{array}{l}\text { smith, Arthur } w \text {. } \\
\text { Box } 3-252 \text {, Eastchester Branch } \\
\text { Anchorage }\end{array}$ & $\begin{array}{l}\text { White River } \\
\text { McCarthy }\end{array}$ & & Prospecting \\
\hline $\begin{array}{l}\text { Smith, Lauren F. } \\
\text { Gakona }\end{array}$ & $\begin{array}{l}\text { Mankoman Lake } \\
\text { Chitina }\end{array}$ & & Prospecting \\
\hline $\begin{array}{l}\text { Stanley, Kirk W. } \\
7003 \text { Mink Place } \\
\text { Anchorage }\end{array}$ & $\begin{array}{l}\text { Slana district } \\
\text { Chitina }\end{array}$ & 25 & Drilling \\
\hline $\begin{array}{l}\text { Stout, A1 } \\
\text { Kobuk }\end{array}$ & $\begin{array}{l}\text { Dah1 Creek } \\
\text { Noatak-Kobuk }\end{array}$ & 2 & Nonfloat \\
\hline $\begin{array}{l}\text { Sume, Ron } K \text {. } \\
\text { General Delivery } \\
\text { Anchorage }\end{array}$ & $\begin{array}{l}\text { Knik Glacier } \\
\text { Palmer }\end{array}$ & & Prospecting \\
\hline $\begin{array}{l}\text { Superior } 0 \text { il Company } \\
1 \text { East lst Street } \\
\text { Reno, Nevada }\end{array}$ & $\begin{array}{l}\text { Muir Inlet } \\
\text { Juneau }\end{array}$ & 10 & $\begin{array}{l}\text { Drilling molybdenum } \\
\text { prospect }\end{array}$ \\
\hline $\begin{array}{l}\text { Tennessee Corp. } \\
61 \text { Broadway } \\
\text { New York }\end{array}$ & $\begin{array}{l}\text { Alaska general } \\
\text { Several }\end{array}$ & 8 & Recon exploration \\
\hline $\begin{array}{l}\text { Thomas, Joe } \\
\text { Sitka }\end{array}$ & $\begin{array}{l}\text { Chichagof Mine } \\
\text { Sitka }\end{array}$ & 2 & Development \\
\hline $\begin{array}{l}\text { Totem Exploration Co. } \\
\text { Joe Blazek } \\
317 \text { Dock Street } \\
\text { Ketchikan }\end{array}$ & $\begin{array}{l}\text { Southeastern Alaska } \\
\text { Several }\end{array}$ & ] & Prospecting \\
\hline $\begin{array}{l}\text { Trumpey, Charlie } \\
\text { General Delivery } \\
\text { Fairbanks }\end{array}$ & $\begin{array}{l}\text { Omega Creek } \\
\text { Manley Hot Springs }\end{array}$ & 1 & Nonfloat \\
\hline $\begin{array}{l}\text { Tweet, N. B. \& Sons } \\
\text { Teller }\end{array}$ & $\begin{array}{l}\text { Kougarok River } \\
\text { Cape Nome }\end{array}$ & 6 & Nonf loat \\
\hline $\begin{array}{l}\text { Tweiten, Oscar } \\
\text { Box } 162 \\
\text { Fairbanks }\end{array}$ & $\begin{array}{l}\text { Chatham Creek } \\
\text { Fairbanks }\end{array}$ & 1 & Sma 11 scale hand \\
\hline $\begin{array}{l}\text { U. S. Steel Corp. } \\
525 \text { Williall Penn Place } \\
\text { Pittsburgh, Pa. }\end{array}$ & $\begin{array}{l}\text { Alaska general } \\
\text { Several }\end{array}$ & 2 & Development \\
\hline
\end{tabular}


U.S.S.R. \& M. CO.

Box 1170

Fairbanks

Utah Construction \& Mining Co.

718-510 W. Hastings Street

Vancouver, B. C.

Vetter, Rudy \& Adolph

1425 Ash Street

Fairbanks

Vogler, Joe (Joseph E.)

Box 7

Fairbanks

Wa1per, James A.

25212 12th Avenue RR 3

Alder Grove, B. C.

Walsh, Pearce

Nome

Warwick, Bill (William W.)

315 5th Avenue

Fairbanks

Weston, Dave (David M.)

Box 1938

Fairbanks

Wigger, Walter

900 Park Drive

Fairbanks

Wilkey, Jack

Fairbanks

Wilson, Starkey A.

852 Wilson Building

Dallas, Texas

Wolff, Ernest

Colorado State University

Fort Collins, Colorado

Woodman, I. N.

Box 573

Valdez

Worthington, John

Ketchikan

Wylie, James R.

Box 208

Aptos, California

Wright, Virgil $\mathrm{J}$.

Box 980 , Sitka
Hogatza River

20

Nulato

Alaska general

Several

Cleary Summit

Fairbanks

Deadwood Creek

Fairbanks

Southeastern A Iaska

Ketchikan

Seward Peninsula

Cape Nome

Fortymi le

Fairbanks

Dome Creek (40-mile)

Fairbanks

Eva Creek

Fairbanks

Canyon Creek (40-mile)

Fairbanks

Alaska general

Severa 1

Boulder Creek

Manley Hot Springs

2

Tonsina Lake area

Valdez

Prince of Wales Island 1

Ketchikan

Kuskokwim

Kuskokwim

Herbert Groves Island Sitka
Gold dredge and Alaska exploration general

Exploration

Gold lode development

Nonfloat

Prospecting

Mining promotion

Mercury development

Nonfloat

Nonfloat

Nonfloat

Investigations

Prospecting

Prospecting

Prospecting

$5 \quad$ Prospecting

Prospecting 
"Nonfloat" indicates mechanical placer gold operation using draglines and/or bulldozers to transport gravel to nonfloating washing plant, bedrock sluiceboxes, or elevated sluices.

"Hydraulic" indicates placer gold operation in which gravel is excavated and transported to sluiceboxes solely by water jets from hydraulic nozzles.

"Small scale hand" indicates placer gold operation in which gravel excavation and transportation is accomplished by hand or ground sluicing.

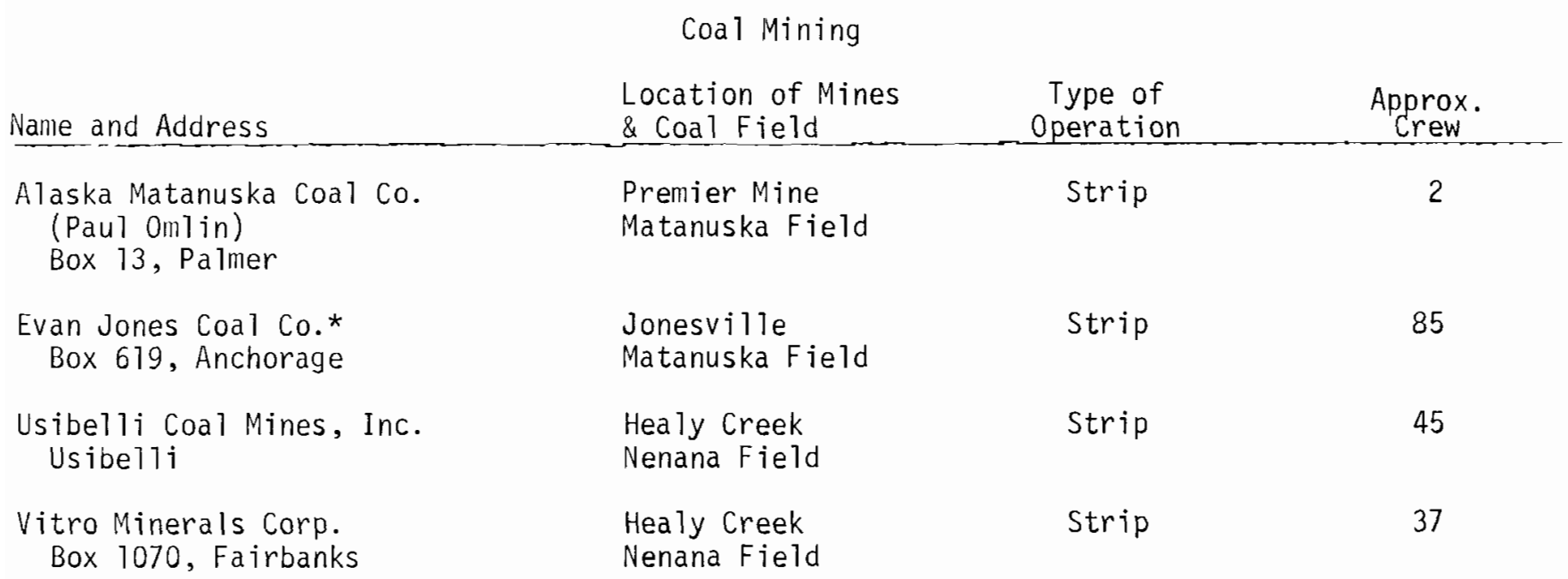

Note: Above data from DM\&G records.

* Evan Jones was active at Jonesville until April, at which time the mine was closed. 
*Report of the Mine Inspector for the Territory of Alaska to the Secretary of the Interior, fiscal year ended June 30, 1912.

*Report of the Mine Inspector for the Territory of Alaska to the Secretary of the Interior, fiscal year ended June 30, 1913.

*Report of the Mine Inspector for the Territory of Alaska to the Secretary of the Interior, fiscal year ended June 30, 1914.

*Report of the Territorial Mine Inspector to the Governor of Alaska for the year 1915.

*Report of William Maloney, Territorial Mine Inspector, to the Governor of Alaska for the year 1916.

*Report of the Territorial Mine Inspector to the Governor of Alaska for the year 1917.

*Annual Report of the Territorial Mi Inspector to the Governor of Alaska, 1920.

*Annual Report of the Territorial Mine Inspector to the Governor of Alaska, 1921.

*Annual Report of the Mine Inspector to the Governor of Alaska, 1922.

*Annual Report of the Mine Inspector to the Governor of Alaska, 1923.

* Report upon Industrial Accidents Compensation and Insurance in Alaska for the biennium ending December 31, 1924.

*Report of the Territorial Mine Inspector, calendar years 1925-26.

*Report of cooperation between the Territory of Alaska and the United States in making mining investigations and in the inspection of mines for the biennium ending March 31, 1929.

* Report of cooperation between the Territory of Alaska and the United States in making mining investigations and in the inspection of mines for the biennium ending March 31, 1931.

*Mining Investigations and Mine Inspection in Alaska, biennium ending March 31, 1933.

*Report of the Commissioner of Mines to the Governor, biennium ending December 3T, 1936.

*Report of the Commissioner of Mines to the Governor, biennium ending December 31, 1938.

*Report of the Commissioner of Mines to the Governor, biennium ending December 31, 1940.

*Report of the Commissioner of Mines to the Governor, two biennia ended December 31, 1944.

*Report of the Commissioner of Mines, biennium ended December 31, 1946.

*Report of the Commissioner of Mines, biennium ended December 31, 1948.

*Report of the Commissioner of Mines, biennium ended December 31, 1950.

* Report of the Commissioner of Mines, biennium ended December 31, 1952.

*Report of the Commissioner of Mines, biennium ended December 31, 1954.

*Report of the Commissioner of Mines, biennium ended December 31, 1956.

*Report of the Commissioner of Mines, biennium ended December 31, 1958. 
*Report of the Division of Mines and Minerals for the year 1959.

Report of the Division of Mines and Minerals for the year 1960.

*Report of the Division of Mines and Minerals for the year 1961.

*Report of the Division of Mines and Minerals for the year 1962.

Report of the Division of Mines and Minerals for the year 1963.

Report of the Division of Mines and Minerals for the year 1964.

Report of the Division of Mines and Minerals for the year 1965.

*Report of the Division of Mines and Minerals for the year 1966.

Report of the Division of Mines and Minerals for the year 1967.

*Joesting, Henry R., Strategic Minera 1 0ccurrences in Interior Alaska, Pamphlet \#1, May 1942.

*Joesting, Henry R., Supplemental to Pamphlet \# 1 - Strategic Mineral Occurrences in Interior Alaska; Pamphlet \#2, March 1943.

*Anderson, Eskil, Mineral 0ccurrences other than Gold Deposits in Northwestern Alaska; Pamphlet \#5-R, May 1944.

*Stewart, R. L., Prospecting in Alaska (26-page pamphlet) December 1944. (Revised to November 1949)

*Glover, A. E., Industrial Minerals as a Field for Prospecting in Alaska, including a Glossary of Elements and Minera Ts (82-page booklet) March 1945. (Revised to May 1946)

*Anderson, Eskil, Asbestos and Jade Occurrences in the Kobuk River Region, Alaska; Pamphlet \#3-R, May 1945.

*Roehm, J. C., Some High Calcium Limestone Deposits in Southeastern Alaska; Pamphlet \#6, March 1946. Mimeographed copies are available

Information Circular \#1: Proper Claim Staking in Alaska; Revised March 1, 1968.

Information Circular \#2: Mineral Rights of Aliens in the State; Revised March 1, 1968.

Information Circular \#3: Hand Placer Mining Methods; Revised March 5, 1968.

Information Circular \#4: Uranium Prospecting in Alaska; Revised March 7, 1968.

Information Circular \#5: General Alaskan Mineral Information; Revised March 7, 1968.

Information Circular \#6: Alaskan Prospecting Information; Revised March 8, 1968.

*Information Circular \#7: Compulsory Assessment Work Affidavits; Discontinued.

Information Circular \#8: Mineral Industry Consultants Available for Work in Alaska; Revised Apri1 2, 1968.

Information Circular \#9: Dealers in Alaskan Rocks and Minera1s; Revised October 10, 1968.

Information Circular \#10: Skin Diving for Gold in Alaska; Revised Apri1 2, 1968.

Information Circular \#11: List of Division of Mines and Geology publications; Revised October 10, 1968. 
Information Circular \#12: Services of the Division of Mines and Minerals; Revised Apri] 20, 1968.

Information Circular \#13: Dangers in 01d Mine Openings, November 6, 1962.

Information Circular \#14: Mining Laws Applicable in Alaska; Revised November 15, 1966.

Race, William H., The Mineral Industry of the Kenai-Cook Inlet-Susitna Regions, 1962.

*Report No. PE 85-22; Report on Preliminary Investigation of the Kings River Area Limestone Deposits, Anchorage Quadrangle, by Martin W. Jasper and Miro Michelich, State Mining Engineers, January 1961.

Report No. PE 65-1; Report on the Mespelt Mine of Strandberg Mines, Inc., Nixon Fork District Medfra Quadrangle, Alaska, by Martin W. Jasper, State Mining Engineer, February 1961.

Alaska's New Mining Law for State Lands, by James A. Williams, Director, State Division of Mines and Minerals, December 1961 (Reprinted from Mining Engineering Magazine).

Geology and Ore Deposits of Alaska, by Gordon Herreid, Geologist, State Division of Mines and Minerals, December 1961 (Reprinted from Mining Engineering Magazine).

Tectonics and Ore Deposits in Alaska, by Gordon Herreid, Mining Geologist, State Division of Mines and Minerals. Presented at the 1964 Alaska AIME conference, College, Alaska, March 19, 1964.

A Possible Guide to Metal Deposits of Alaska, by Charles F. Herbert, Deputy Commissioner, State Department of Natural Resources. Presented at the 1964 Alaska AIME conference, College, Alaska, March 20, 1964.

Map: Better-Known Mineral Deposits, Possible Petroleum Provinces, and Existing Roads.

Map: M.I. Report 194-1; A Preliminary Map of the Bedrock Geology of the Fairbanks Mining District, Alaska, by Robert B. Forbes and Jim M. Brown, Department of Geology, Col Tege of Earth Sciences and Mineral Industry, University of Alaska for the Division of Mines and Minerals, December 1961. Price $\$ 1.00$

Geologic Report \#1: Preliminary Report on Geologic Mapping in the Coast Range Mineral Be1t, by G. Herreid. This report formerly included in Annual Report of the Division of Mines and Minerals for the year 1962 but supply exhausted. Now available in reprint form. Price $\$ 1.00$

*Geologic Report \#2: Bedrock Geology of the Rainbow Mountain Area, Alaska Range, Alaska; an M.S. thesis prepared by Larry G. Hanson of the University of Alaska in cooperation with the Division of Mines and Minera1s, November 1963. Price $\$ 1.00$

*Geologic Report \#3: Geology of the Portage Creek-Susitna River Area, by Donald Richter, 1963. (2 large sheets) Price $\$ 1.00$

Geologic Report \#4: Geology and Mineral Deposits of the Denali-Maclaren River Area, Alaska, by M. A. Kaufman, May 1964. (19 pages \& large map) Price $\$ 1.00$

*Geologic Report \#5: Geology of the Niblack Anchorage Area, Southeastern Alaska, by G. Herreid May 1964. (10 pages \& large map) Price $\$ 1.00$

*Geologic Report \#6: Geology and Mineral Deposits of the Antell Creek Area, Slana District, Southcentral Alaska, by Donald H. Richter, May 1964. (17 pages \& large map) Price $\$ 1.00$

Geologic Report \#7: Geology of the Dry Pass Area, Southeastern Alaska by G. Herreid and M. A. Kaufman, June 1964. (16 pages) Price $\$ 1.00$ 
Geologic Report \#8: Geology of the Paint River Area Iliamna Quadrangle, Alaska, by D. H. Richter \& G. Herreid, January 1965. (18 pages \& map) Price $\$ 1.00$

Geologic Report \#9: A Geologic and Geochemical Traverse Along the Nellie Juan River, Kenai Peninsula, Alaska, by G. Herreid, August 1965. (2 pages \& map) No Charge

*Geologic Report \#10: Geology of the Bluff Area, Solomon Quadrangle, Seward Peninsula, Alaska, by G. Herreid, June 1965. (21 pages \& large map) Price $\$ 1.00$

Geologic Report \#11: Geology of the Dmilak-0tter Creek Area, Bendeleben Quadrang1e, Seward Peninsula, Alaska, by G. Herreid, June 1965. (12 pages \& large map) Price $\$ 1.00$

*Geologic Report \#12: Geology of the Bear Creek Area, Seward Peninsula, Candle Quadrangle, Alaska, by G. Herreid, May 1965. (16 pages \& map) Price $\$ 1.00$

*Geologic Report\#13: Geology and Geochemical Investigations Near Paxson, Northern Copper River Basin, Alaska, by A. W. Rose and R. H. Saunders, June 1965. (35 pages) Price $\$ 1.00$

*Geologic Report \#14: Geology and Mineral Deposits of the Rainy Creek Area, Mt. Hayes Quadrang1. Alaska, by A. W. Rose. (51 pages \& map) Price $\$ 1.00$

Geologic Report \#15: Geology and Mineralization of the Midas Mine and Sulphide Gulch Areas Near Valdez, Alaska, by A. W. Rose, March 1965. (21 pages \& map) Price $\$ 1.00$

Geologic Report \#16: Geology and Mineral Deposits of Central Knight Island, Prince William Sound, Alaska, by D. H. Richter, July 1965. (37 pages \& maps) Price $\$ 1.00$

Geologic Report \#17: Geology and Geochemistry of the Hollis and Twelvemile Creek Areas, Prince of Wales Island, Southeastern Alaska, by G. Herreid and Arthur W. Rose, April 1966. (32 pages with numerous maps and figures) Price $\$ 1.00$

Geologic Report \#18: Geology of Chromite-Bearing Ultramafic Rocks Near Eklutna, Anchorage Quadrangle, Alaska, by A. W. Rose, May 1966. (20 pages, maps and figures) Price $\$ 1.00$

Geologic Report \#19: Geology of part of the Amphitheatre Mountains, Mt. Hayes Quadrangle, Alaska, by A. W. Rose, February 1966. (14 pages, includes maps and figures) Price $\$ 1.00$

Geologic Report \#20: Geological and Geochemical Investigations in the Eureka Creek and Rainy Creek Areas, Mt. Hayes Quadrangle, Alaska, by A. W. Rose, June 1966. (Includes tables \& maps) Price $\$ 1.00$

Geologic Report \#21: Geology of the Slana District, Southcentral Alaska, by D. H. Richter, July 1966. (51 pages \& maps) Price $\$ 1.00$

Geologic Report \#22: Geology and Geochemistry of the Nixon Fork Area, Medfra Quadrangle, Alaska, by G. Herreid, July 1966. (37 pages) Price $\$ 1.00$

Geologic Report \#23: The Geology and Geochemistry of the Inmachuk River Map Area, Seward Peninsula, Alaska, by G. Herreid, November 1966. (25 pages \& map) Price $\$ 1.00$

Geologic Report \#24: Preliminary Geology and Geochemistry of the Sinuk River Area, Seward Peninsula, Alaska, by G. Herreid, May 1966. (19 pages \& map) Price $\$ 1.00$

Geologic Report \#25: Geological and Geochemical Investigations in the Metal Creek Area, Chugach Mountains, A]aska, by D. H. Richter, May 1967. Price $\$ 1.00$

Genlonic Report \#26: Geological and Geochemical Investigations Southwest of Farewe11, Alaska, by G. Herreid, July 1968. Price $\$ 1.00$ 
Geologic Report \#27: Geology and Mineral Deposits of the Dolomi Area, Prince of Wales Island, Alaska, by G. Herreid, June 1967. Price $\$ 1.00$

Geologic Report \#28: Geology of the Upper Chistochina River Area, Mt. Hayes Quadrangle, Alaska, by A. W. Rose, February 1967. Price $\$ 1.00$

Geologic Report \#29: Progress Report on the Geology and Geochemistry of the Sinuk Area, Seward Peninsula, Alaska, by G. Herreid, July 1968. Price $\$ 1.00$

Geologic Report \#30: Geology of the Upper Slana - Mentasta Pass Area, Southcentral Alaska, by D. H. Richter, May 1967 . Price $\$ 1.00$

Geologic Report \#31: Geology and Stream Sediment Geochemistry of Anton Larsen Bay and Vicinity, Kodiak Island, Alaska, by A. W. Rose and D. H. Richter, April 1967. Price \$1.00

Geologic Report \#32: Geology of an Area on the Upper Talkeetna River, Talkeetna Mountains Quadrangle, Alaska, by A. W. Rose, February 1967. Price $\$ 1.00$

*Geochemical Report \#1: Geochemical Investigations of Selected Areas in Southeastern Alaska, by C. F. Herbert and W. H. Race, November 1964. Out of Print. Has been included with 1965 work in Geochemical Report \#6 covering both years.

*Geochemical Report \#2: Geochemical Investigation of the Slana District, Southcentral Alaska, 1963 and 1964, by D. H. Richter, March 1965. (14 pages \& map) Price $\$ 7.00$

*Geochemical Report \#3: A Geochemical Investigation in the Richardson Area, Big Delta Quadrangle, Alaska, by R. H. Saunders, April 1965. (11 pages \& maps) Price $\$ 1.00$

Geochemical Report \#4: Geochemical Investigations of Selected Areas in Southcentral Alaska, 1964 , by M. W. Jasper, May 1965 . (31 pages \& map) Price $\$ 1.00$

Geochemical Report \#5: A Geochemical Investigation Between Chatanika and Circle Hot Springs, Alaska, by W. M. Burand, May 1965. (11 pages, 2 plates) Price $\$ 1.00$

Geochemical Report \#6: Geochemical Investigations of Selected Areas in Southeastern Alaska, 1964 and 1965, by C. F. Herbert and W. H. Race, December 1965. (66 pages, plus maps and figures) Price $\$ 1.00$

Geochemical Report \#7: Geochemical Investigations Along Highway and Secondary Roads in Southcentral Alaska, 1965, by M. W. Jasper, July 1966. (8 pages, various tables and illustrations) Price $\$ 1.00$

Geochemical Report \#8: Geochemical and Geological Investigations of Admiralty Island, Alaska, by W. H. Race and A. W. Rose, March 1967. Price $\$ 1.00$

Geochemical Report \#9: A Geochemical Investigation Along the Taylor Highway, East-Central Alaska, by R. H. Saunders, February 1966. (17 pages \& appendix) Price $\$ 1.00$

Geochemical Report \#10: A Geochemical Investigation of the Nenana Highway Area, Central Alaska, by W. M. Burand, April 1966. (13 pages including figures and maps) Price $\$ 1.00$

Geochemical Report \#11: A Geochemical Investigation of Stream Sediments in the El1iott Highway Area, Alaska, by W. M. Burand, July 1966. (17 pages and numerous figures) Price $\$ 1.00$

Geochemical Report \#12: A Geochemical Investigation of Minook Creek, Rampart District, Alaska, by W. M. Burand and R. H. Saunders, Apri1 1966. (15 pages \& appendix) Price $\$ 1.00$ 
Geochemical Report \#13: Geochemical Investigations of Selected Areas in the Yukon-Tanana Region of Alaska, 1965 and 1966, by W. M. Burand, May 1968. Price $\$ 1.00$

Geochemical Report \#14: Geochemical Investigations Willow Creek Southerly to Kenai Lake Region Southcentral Alaska, by M. W. Jasper, June 1967. Price $\$ 1.00$

Geochemical Report \#15: Geochemical Investigations Along the Valdez tc Chitina Highway in Southcentral Alaska, 1966, by M. W. Jasper, Apri1 1967. Price $\$ 1.00$

Geochemical Report \#16: A Geochemical Investigation of a Portion of the Fortymile District, Alaska, by W. H. Smith, June 1968. Price $\$ 1.00$

Geochemical Report \#17: A Geochemical Investigation of the Wood River-Tikchik Lakes Area, Southwestern Alaska, by G. R. Eakins, May 1968. Price $\$ 1.00$

The Great A1aska Earthquake, March 27, 1964: May 19, 1964.

Mine Safety Regulations, 1963, from the Alaska Administrative Code.

Special Reports:

Mineral Occurrences in the Yukon-Tanana Region, Alaska, by R. H. Saunders, April 1967. Price $\$ 1.00$

History of Mines and Prospects, Ketchikan District, Prior to 1952, by John Bufvers. Price $\$ 1.00$

* Dut of Print. On file in certain public and Iniversity libraries. 